\title{
Efeitos da Reforma Trabalhista na Justiça do Trabalho: Análise da Dinâmica Processual na SEgunda VARA do trabalho de Santa Maria/RS
}

\author{
Effects of Workist Reform on Labor Justice: \\ Analysis of Processual Dynamics in the Second \\ LABOR COURT OF SANTA Maria/RS
}

\author{
Efectos de la Reforma Obrera en la Justicia \\ Laboral: Análisis de la Dinámica Procesual en \\ EL SEGUNDO TRIBUNAL DEL TRABAJO DE SANTA \\ Maria/RS
}

Paulo José Libardoni ${ }^{*}$ Rodrigo Wasem Galia*

1 Introdução. 2 Um universo processual em tramitação. 2.1 Ações de Cumprimento - 2019. 2.2 A redução do número de casos novos no Rito Ordinário (RO) do ano de 2017 para 2018 e a sua constância em 2019. 2.3 A elevação do número de ações no rito sumário em 2019. 2.4 A constância no número de ações no rito sumaríssimo. $2.5 \mathrm{~A}$ redução do número de homologações de acordo extrajudicial de 2018 para 2019. 3 Considerações finais. Referências.

\footnotetext{
"Doutor em Sociologia - Universidade Federal do Rio Grande do Sul (UFRGS). Docência no Curso Pós-Graduação, Pesquisa Jurídica Trabalhista e Profissional Liberal (Advogado Trabalhista). Filiação institucional: Faculdade Metodista Centenário (FMC). Santa Maria, RS, BR. E-mail: <libardoniadv@hotmail.com>. https://orcid.org/0000-0003-3596-9922

**ós-Doutor em Direito pela PUCRS (2019). Professor do Mestrado em Direito da UFSM. Professor Adjunto de Direito do Trabalho, Direito Processual do Trabalho e de Direito Previdenciário do Curso de Direito da UFSM. Santa Maria, RS, BR. E-mail: <rodrigogalia@hotmail.com>. http://orcid.org/0000-0002-6364-0262
} 
Efeitos da reforma trabalhista na justiça do trabalho: análise da dinâmica processual na segunda vara do trabalho de Santa Maria/RS

\section{RESUMO}

Objetivos: A Reforma Trabalhista, operada pela Lei $\mathrm{n}^{\circ}$ 13.467/2017, trouxe modificações substanciais ao Direito Processual do Trabalho. Nesse sentido, o presente artigo destina-se a analisar tais impactos reformistas na seara processual trabalhista, mormente na dinâmica processual trabalhista, operadas na segunda Vara do Trabalho de Santa Maria/RS, que reclamam uma nova e diferenciada atuação dos profissionais que atuam na área trabalhista (advogados e contadores).

Metodologia: $O$ presente estudo constitui-se como uma sistematização de dados quantitativos da segunda Vara do Trabalho de Santa Maria apresentados pelo sistema do Tribunal Regional do Trabalho da 40 Região a partir do ano de 2012 até 2019, seguida por revisões bibliográfica e legislativa que seguem o método dedutivo. Utiliza-se de pesquisa de campo complementada por um aporte bibliográfico, legislativo e doutrinário multidisciplinar e interdisciplinar.

Resultados: Várias alterações processuais trabalhistas foram operadas pela Reforma Trabalhista. Dessa forma, conclui-se que houve modificações na distribuição quantitativa das ações por rito, entretanto manteve-se constante o número total de ações ajuizadas.

Contribuições: A principal contribuição desta pesquisa reside na possibilidade de se refletir e de se indagar sobre os impactos da Reforma Trabalhista nas ações judiciais que tramitam na segunda Vara do Trabalho de Santa Maria-RS (Justiça do Trabalho).

Palavras-chave: Reforma Trabalhista. Pesquisa Quantitativa. Pesquisa Doutrinária. Ações Judiciais. Justiça do Trabalho.

\section{ABSTRACT}

Objectives: The Labor Reform, operated by Law no 13,467 / 2017, brought substantial changes to the Labor Procedural Law. In this sense, the present article aims to analyze such reformist impacts in the laborist procedural area, especially in the labor procedural dynamics, operated in the second Labor Court of Santa Maria / RS, which demand a new and a differentiated performance of the professionals who work in the labor area (lawyers and accountants).

Methodology: The present study constitutes a systematization of quantitative data from the second Labor Court of Santa Maria presented by the system of the Regional Labor Court of the 4th Region from the year 2012 to 2019, followed by bibliographic and 
legislative reviews that follow the deductive method. It uses field research complemented by a multidisciplinary and interdisciplinary bibliographic, legislative and doctrinal aport.

Results: Several labor procedural changes were operated by the Labor Reform. Thus, it is concluded that there were changes in the quantitative distribution of the shares per rite, however, the total number of lawsuits remained constant.

Contributions: The main contribution of this research resides in the possibility of reflecting and inquiring about the impacts of the Labor Reform in the lawsuits that are being processed in the second Labor Court of Santa Maria-RS (Labor Justice).

Keywords: Labor reform. Quantitative research. Doctrinal research. Judicial actions. Work justice.

\section{RESUMEN}

Objetivo: La Reforma Laboral, impulsada por la Ley no 13.467 / 2017, trajo cambios sustanciales a la Ley Procesal Laboral. En este sentido, el presente artículo tiene como objetivo analizar tales impactos reformistas en el área procesal laborista, especialmente en la dinámica procesal laboral, operada en el segundo Juzgado Laboral de Santa María / RS, que demandan una actuación nueva y diferenciada de los profesionales que actuar en el area laboral (abogados y contadores).

Metodología: El presente estudio constituye una sistematización de datos cuantitativos del segundo Juzgado Laboral de Santa María presentados por el sistema del Juzgado Regional del Trabajo de la 4a Región del año 2012 al 2019, seguido de revisiones bibliográficas y legislativas que siguen el método deductivo. Utiliza una investigación de campo complementada con aporte bibliográfico, legislativo y doctrinal multidisciplinario e interdisciplinario.

Resultados: La Reforma Laboral trajo varios cambios procesales laborales. Así, se concluye que hubo alteraciones en la distribución cuantitativa de acciones por rito, sin embargo, el número total de reclamos se mantuvo constante.

Contribuciones: La principal contribución de esta investigación reside en la posibilidad de reflexionar e indagar sobre los impactos de la Reforma Laboral en las acciones judiciales que se tramitan en el Segundo Juzgado Laboral de Santa María-RS (Justicia Laboral).

Palabras clave: Reforma laboral. Investigación cuantitativa. Investigación doctrinal. Acciones judiciales. Trabajar justicia. 
Efeitos da reforma trabalhista na justiça do trabalho: análise da dinâmica processual na segunda vara do trabalho de Santa Maria/RS

\section{INTRODUÇÃO}

O artigo destina-se a analisar os impactos da Reforma Trabalhista na dinâmica das Ações Judiciais que tramitam na Justiça do Trabalho (Lei no 13.467/2017), em especial na $2^{\circ}$ Vara do Trabalho de Santa Maria/RS. As alterações legislativas afetaram, em medidas distintas, o funcionamento e os procedimentos das ações judiciais. Àquelas somam-se, ainda, como relevante, os efeitos da implantação da plataforma processual eletrônica ou Processo Judicial Eletrônico (PJe).

Com lapsos temporais de 04 anos de vigência do Código de Processo Civil, que afetou alguns procedimentos judiciais laborais; 02 anos da Reforma Trabalhista e 05 anos de implantação do PJe, começam a ganhar destaque algumas relevâncias estatísticas que resultam em acontecimentos fáticos e judiciais vivenciados pelos profissionais que atuam na Justiça do Trabalho. Por outro lado, mesmo sendo exíguos tais lapsos temporais, a realidade judicial apresenta algumas pistas aptas a serem analisadas e compartilhadas.

Não há propriamente uma pretensão doutrinária neste artigo, os autores se propuseram a analisar as mudanças legislativas aptas a explicar as variações quantitativas apresentadas pelos dados gerados pelo sistema do Tribunal Regional do Trabalho da $4^{\circ}$ Região, a contar do ano de 2012 até outubro de 2019.

A partir de uma perspectiva multicausal, quando é variado e amplo o conjunto de elementos aptos a influir em dado acontecimento judicial, conclui-se que as variações quantitativas apresentadas pelos dados em análise resultam das modificações legais que as antecederam, desse modo, a Reforma Trabalhista impactou a dinâmica processual da 2a Vara do Trabalho de Santa Maria - RS em medidas e ações distintas. Aos poucos, pretende-se investigar as demais Varas do Trabalho de Santa Maria - RS e de outros municípios gaúchos.

Por fim, os impactos mais relevantes foram a elevação do número de ações de cumprimento; a redução do número de ações ajuizadas no rito ordinário; a elevação do número de ações ajuizadas no rito sumário; a suave elevação do número de ações ajuizadas no rito sumaríssimo e a redução do número de homologações de acordos extrajudiciais. Dessa forma, a reforma trabalhista gerou certa mudança na dinâmica das ações judiciais a partir de sua publicação e vigência.

Os dados quantitativos foram coletados a partir do sistema do Tribunal Regional do Trabalho da 4o Região, sendo analisados e sistematizados via Excel, em vista da simplicidade das informações postas em análise. As tabelas e os gráficos que seguem são uma parte do trabalho a que se destina o projeto de pesquisa viabilizado pelo convênio entre o Tribunal Regional do Trabalho da 4o Região (TRT4) e a Universidade Federal de Santa Maria (UFSM) por seu Departamento de Pós-Graduação em Direito por meio 
do Projeto de Pesquisa GPRETRADE ${ }^{1}$ - As relações de trabalho no século XXI e os novos desafios da sociedade em rede. Tal projeto e dados são restritos à análise das informações jurídicas e processuais.

A Justiça do Trabalho de Santa Maria é composta por três juízes, atendendo a um conjunto amplo de municípios jurisdicionados, como segue: Dilermando de Aguiar, Dona Francisca, Faxinal do Soturno, Formigueiro, Itaara, Ivorá, Jari, Júlio de Castilhos, Mata, Nova Palma, Pinhal Grande, Quevedos, Restinga Seca, Santa Maria, Silveira Martins, São João do Polêsine, São Martinho da Serra, São Pedro do Sul, São Sepé, Toropi. A Vara do Trabalho foi instalada em 25/03/1993, e o Processo Judicial Eletrônico fora implantado em 24/10/2014².

No ano de 2019, utilizaram-se os dados até outubro (incluído), em vista do momento de acesso às informações, pois fora percebido, depois de analisá-los, que havia um padrão de informações suficientes e harmônicas aptas à aproximação com os anos anteriores.

Buscou-se, previamente, dialogar com os profissionais da Vara do Trabalho, com as partes e advogados buscando acessar o conhecimento acumulado e as pistas produzidas sobre o andamento processual pós reforma trabalhista. As hipóteses levantadas e as causas prováveis sobre os impactos nas dinâmicas processuais partiram da experiência profissional vivenciada. Estas são algumas das técnicas de pesquisa realizadas pelos autores aptas à qualificação da pesquisa qualitativa e empírica na seara do direito.

Houve também a necessidade do acesso aos autos processuais por parte dos pesquisadores, para verificar, ratificar, retificar ou rejeitar algumas das hipóteses, reforçando a veracidade das informações levantadas, além da confirmação dos dados fornecidos pelo sistema.

\section{UM UNIVERSO PROCESSUAL EM TRAMITAÇÃO}

A tabela que segue apresenta a integralidade dos dados acessados entre o ano de 2012 a outubro de 2019. Dessa totalidade, optou-se por uma amostra inicial focada em algumas variações, como segue: As ações de cumprimento de sentença do ano de 2018 para 2019; a redução do número de casos novos no rito ordinário do ano de 2017 para 2018 e a sua constância em 2019; a elevação do número de casos novos no rito sumário do ano de 2018 para 2019; a elevação no número de casos novos no rito sumaríssimo e a redução do número de homologações de acordos extrajudiciais do ano de 2018 para 2019.

1 dgp.cnpq.br/dgp/espelhogrupo/7845260409399790

2 https://www.trt4.jus.br/portais/trt4/relatorios-de-correicao-2019 
Efeitos da reforma trabalhista na justiça do trabalho: análise da dinâmica processual na segunda vara do trabalho de Santa Maria/RS

Quadro 1 - Relação total de processos por classes e ano

\begin{tabular}{|c|c|c|c|c|c|c|c|c|}
\hline \multicolumn{9}{|c|}{ Processos Distribuídos - Casos Novos - 2012 / out-2019 } \\
\hline CLASSE PROCESSUAL & 2012 & 2013 & 2014 & 2015 & 2016 & 2017 & 2018 & 2019 \\
\hline Ação Civil Coletiva & $\mathrm{x}$ & $\mathrm{x}$ & $\mathrm{x}$ & 1 & 1 & 2 & 1 & $\mathrm{x}$ \\
\hline Ação Civil Pública & 6 & 5 & 9 & 7 & 6 & 3 & 6 & 17 \\
\hline Ação de Cumprimento & 15 & 5 & 16 & 5 & 9 & 4 & 6 & 49 \\
\hline Ação Trabalhista - Rito Ordinário & 713 & 794 & 838 & 853 & 842 & 990 & 402 & 383 \\
\hline Ação Trabalhista - Rito Sumário & 9 & 4 & 4 & 7 & 8 & 14 & 12 & 166 \\
\hline Ação Trabalhista - Rito Sumaríssimo & 350 & 262 & 248 & 391 & 368 & 377 & 370 & 444 \\
\hline Alvará Judicial & 2 & 1 & 3 & $x$ & $x$ & $x$ & $x$ & 1 \\
\hline Alvará Judicial - Lei 6858/80 & $x$ & $x$ & $x$ & 1 & 1 & 1 & 2 & 2 \\
\hline Arresto & $\mathrm{x}$ & $x$ & 1 & $\mathrm{x}$ & $x$ & $x$ & $x$ & $x$ \\
\hline Cautelar Inominada & 3 & 4 & 2 & 6 & 7 & $x$ & $x$ & $x$ \\
\hline Consignação em Pagamento & 33 & 47 & 47 & 36 & 24 & 35 & 30 & 24 \\
\hline Contraprotesto Judicial & 1 & $x$ & $x$ & $x$ & $x$ & $\mathrm{x}$ & $x$ & $x$ \\
\hline Embargos de Terceiro & 8 & 6 & 8 & $x$ & $x$ & 4 & 13 & 4 \\
\hline Exibição & 1 & $x$ & $x$ & 1 & 1 & $\mathrm{x}$ & $x$ & $x$ \\
\hline Homologação de Transação Extrajudicial & $x$ & 1 & $\mathbf{x}$ & $\mathbf{x}$ & $x$ & 1 & 16 & 7 \\
\hline Inquérito para Apuração de Falta Grave & 2 & $x$ & 1 & $x$ & $x$ & 1 & $x$ & $x$ \\
\hline Interdito Proibitório & $\mathrm{x}$ & $x$ & 1 & 2 & 1 & 2 & $x$ & $x$ \\
\hline Justificação & $x$ & $x$ & 1 & $x$ & $x$ & $x$ & $x$ & $x$ \\
\hline Mandado de Segurança & $x$ & 2 & 1 & 3 & 6 & 1 & 1 & $x$ \\
\hline Mandado de Segurança Coletivo & $x$ & 1 & $x$ & $\mathrm{x}$ & $x$ & $x$ & $x$ & $x$ \\
\hline Monitória & 1 & $x$ & $x$ & 1 & 1 & $x$ & 1 & $x$ \\
\hline Notificação & $x$ & $\mathrm{x}$ & 6 & $\mathrm{x}$ & $x$ & 1 & $x$ & $x$ \\
\hline Petição & $x$ & 1 & 6 & 3 & 9 & 3 & 4 & 2 \\
\hline Produção Antecipada de Provas & $x$ & $x$ & $x$ & $x$ & $x$ & $x$ & 1 & $x$ \\
\hline Protesto & 1 & 1 & 3 & 1 & 1 & $x$ & $x$ & $x$ \\
\hline Reintegração / Manutenção de Posse & $x$ & $x$ & $x$ & $x$ & 2 & 1 & $x$ & $\mathrm{x}$ \\
\hline Tutela Antecipada Antecedente & $x$ & $\mathrm{x}$ & $\mathrm{x}$ & $\mathrm{x}$ & $x$ & 3 & 4 & 1 \\
\hline Tutela Cautelar Antecedente & $\mathrm{x}$ & $\mathrm{x}$ & $\mathrm{x}$ & $\mathrm{x}$ & $\mathrm{x}$ & $\mathrm{x}$ & $\mathrm{x}$ & 3 \\
\hline \multicolumn{9}{|c|}{ Dados de janeiro de 2012 (até fins de 2014 eram físicos) até outubro de 2019.} \\
\hline \multicolumn{9}{|c|}{$\begin{array}{l}\text { A presença do "x" expressa a não ocorrência e/ou a inexistência da classe em vista da } \\
\text { mudança do CPC/2015 e a Reforma Trabalhista. }\end{array}$} \\
\hline \multicolumn{9}{|c|}{ O Pje foi instalado da Vara do Trabalho em fins de 2014.} \\
\hline \multicolumn{9}{|c|}{ Os números de outubro de 2019 integram os dados tabelados. } \\
\hline
\end{tabular}

Fonte: dados secundários acessados via sistema do PJe - TRT4.

As informações dispostas no Quadro 1 servem para que o leitor possa ter acesso ao universo dos dados acessados, aptos a justificar a centralidade e a escolha para a construção deste artigo nos 05 itens antes definidos, pois o padrão quantitativo das demais classes processuais, no que tange a novas ações, manteve-se ou sofreu variação inexpressiva (não impactadas pela reforma, ou não impactadas ao nível da amostra em 
análise, em vista de estar restrita a uma única Vara do Trabalho, entre outras hipóteses possíveis).

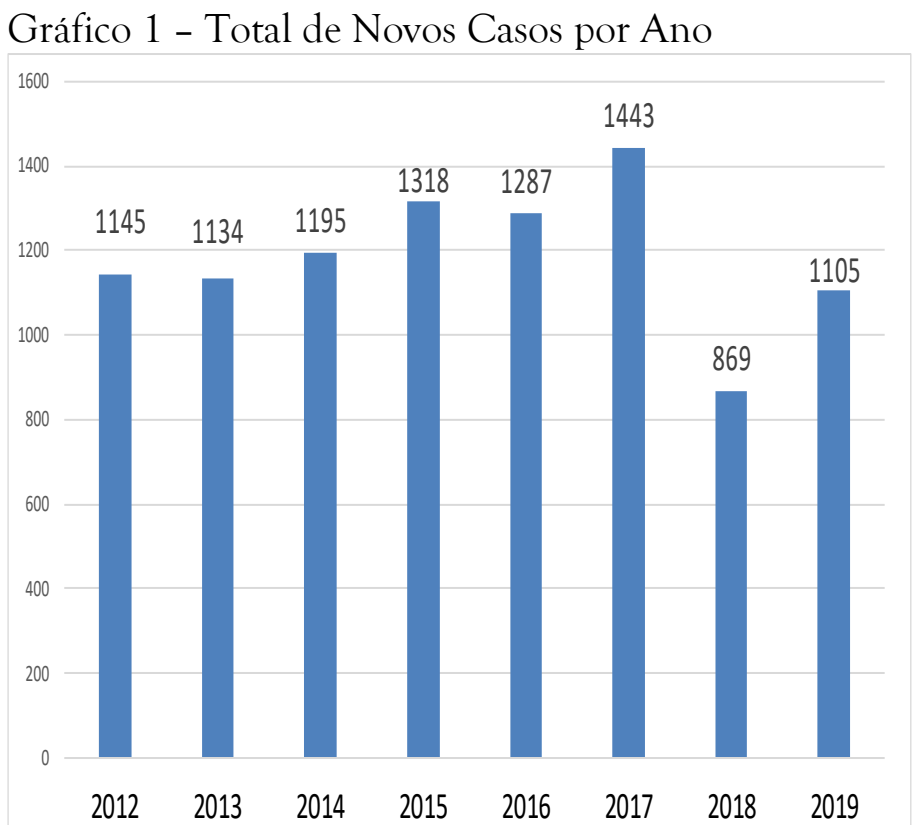

Fonte: dados secundários acessados via sistema do PJe - TRT4.

A partir do Gráfico 1, é preciso antever uma informação e um acontecimento fático-jurídico: a informação apresentada pelos dados demonstram que há uma crescente no número de ações por ano, ressalvado o ano de 2018, que teve uma redução significativa, o que não ocorre em 2019; o acontecimento fático-jurídico apto a explicar tal redução no ano de 2018 está no fato de que, em 2017, houve um aumento do número de novas ações? Da comunhão destes, adiciona-se o prazo de 120 dias do art. $6^{\circ}$ da lei 13.467/2017 (lei da reforma trabalhista) a contar de sua publicação até a entrada em vigor. Nesta linha, muitas novas ações foram protocoladas antes da entrada em vigor da reforma para evitar que as mudanças jurídicas normatizadas impactassem as ações que ora já estariam em curso quando aquela alcançasse a vigência, evitando danos ou riscos aos direitos vindicados. 
Efeitos da reforma trabalhista na justiça do trabalho: análise da dinâmica processual na segunda vara do trabalho de Santa Maria/RS

Gráfico 2 - Casos Novos por Rito e Ano

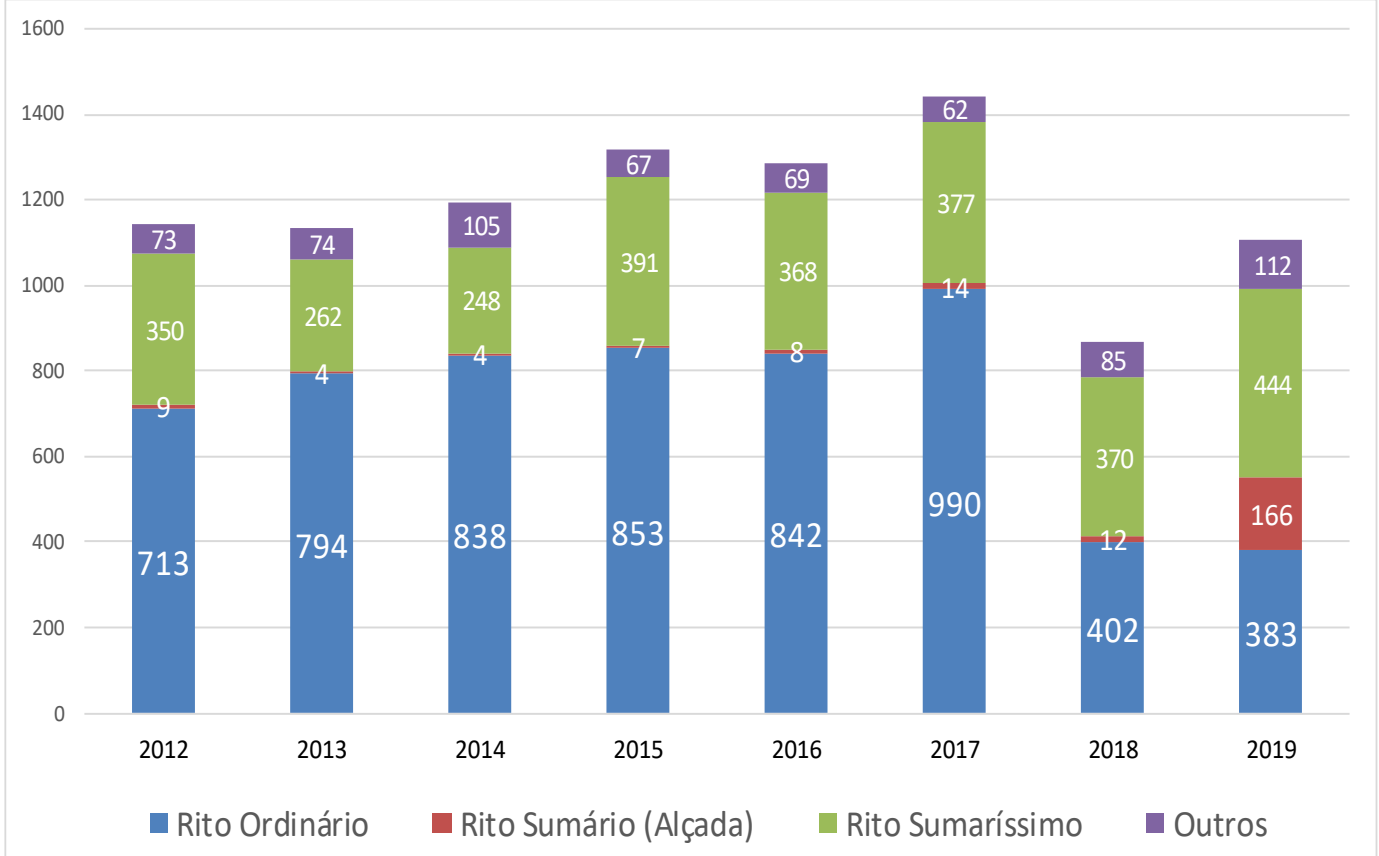

Fonte: dados secundários acessados via sistema do PJe - TRT4.

O Gráfico 2 traz a distribuição das ações por rito (ordinário, sumário, sumaríssimo e outros ${ }^{3}$ ), apta a demonstrar a queda no número de ações distribuídas no rito sumário (que parte de 713 para 383), a importância que ganham o sumário (que parte de 9 para 166) e o sumaríssimo.

Aproximando os Gráficos 1 e 2, percebe-se que o número de novos processos se manteve perto de mil ações novas protocoladas por ano, e que a reforma pode não ter impactado no número total de novas ações a serem julgadas, mas a reforma impactou a distribuição dessas ações entre os ritos.

\subsection{AC̣ÕES DE CUMPRIMENTO ${ }^{4}-2019$}

A maior variação expressa no gráfico que segue levantou interesse nos pesquisadores, quanto ao procedimento da ação de cumprimento, mesmo não tendo

${ }^{3}$ Ação Civil Coletiva / Ação Civil Pública / Ação de Cumprimento / Ação Trabalhista - Rito Ordinário / Ação Trabalhista - Rito Sumário / Ação Trabalhista - Rito Sumaríssimo / Alvará Judicial / Alvará Judicial - Lei 6858/80 / Arresto / Cautelar Inominada / Consignação em Pagamento / Contraprotesto Judicial / Embargos de Terceiro / Exibição / Homologação de Transação Extrajudicial / Inquérito para Apuração de Falta Grave / Interdito Proibitório / Justificação / Mandado de Segurança / Mandado de Segurança Coletivo / Monitória / Notificação / Petição / Produção Antecipada de Provas / Protesto / Reintegração / Manutenção de Posse / Tutela Antecipada Antecedente / Tutela Cautelar Antecedente.

${ }^{4}$ Trata-se aqui da análise das ações de cumprimento na Justiça do Trabalho, que tem por objetivo o cumprimento das normas coletivas (convenção, acordo coletivo ou sentença normativa já pactuados pelos entes coletivos) a teor do art. 872, parágrafo único, da CLT, não das ações de cobrança. 
sofrido alteração legislativa significativa no ano de 2018 ou 2019, capaz de gerar a elevação acentuada do uso dessa modalidade petitória na Justiça do Trabalho.

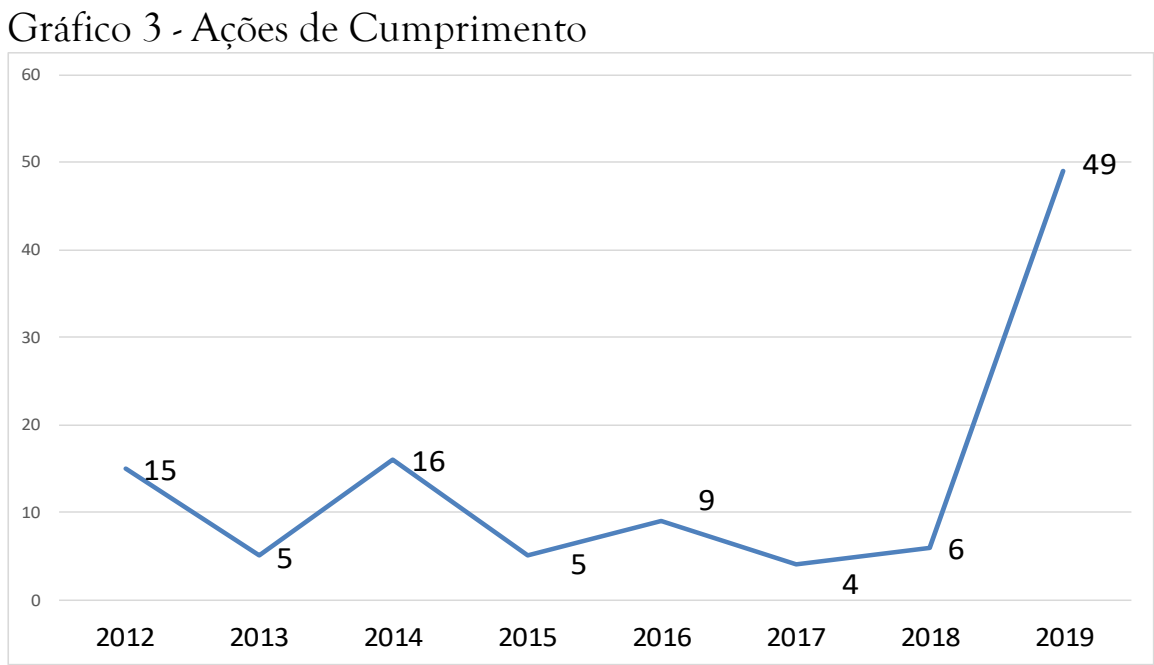

Fonte: dados secundários acessados via sistema do PJe - TRT4.

A elevação do número de ações de cumprimento era inexplicável quando a observação é focada apenas na análise quantitativa, desse modo, os pesquisadores retomaram a verificação dos processos eletrônicos distribuídos, agora com o intuito de verificar parte das informações qualitativas, resultando em:

$>32$ (trinta e duas) Ações de Cumprimento foram propostas por Entidades Sindicais (21) e Federações (11) buscando exigir o adimplemento das violações praticadas em relação às cláusulas ajustadas em Convenções / Acordos Coletivas pelos reclamados ou contribuições sindicais;

$>16$ (dezesseis) Ações de Cumprimento propostas por Sindicatos (processo físico), que sofreram a conversão para PJe (formato eletrônico), possuindo causas diversas;

> 01 (um) Ação de Cumprimento de cunho individual.

As ações propostas pelas entidades sindicais é resultado, em parte, das violações às cláusulas coletivas negociadas e formalizadas, parte pelas mudanças legislativas normatizadas pela reforma nos artigos $578^{5}$ e $579^{6}$ da CLT; e parte pela Medida

5 “Art. 578. As contribuições devidas aos sindicatos pelos participantes das categorias econômicas ou profissionais ou das profissões liberais representadas pelas referidas entidades serão, sob a denominação de contribuição sindical, pagas, recolhidas e aplicadas na forma estabelecida neste Capítulo, desde que prévia e expressamente autorizadas. (Redação dada pela Lei no 13.467, de 2017)." (BRASIL, 1943, online).

6 "Art. 579. O desconto da contribuição sindical está condicionado à autorização prévia e expressa dos que participarem de uma determinada categoria econômica ou profissional, ou de uma profissão liberal, em favor do sindicato representativo da mesma categoria ou profissão ou, inexistindo este, na conformidade do disposto no art. 591 desta Consolidação. (Redação dada pela Lei no 13.467, de 2017)." (BRASIL, 1943, online). 
Efeitos da reforma trabalhista na justiça do trabalho: análise da dinâmica processual na segunda vara do trabalho de Santa Maria/RS

Provisória 873 de 2019, entre outras. A revogação da compulsoriedade, a revogação do recolhimento em folha de salários (boletos) e a necessidade de consentimento por parte do empregado, além de outros fatores, impuseram a redução arrecadatória, que estaria por impactar o orçamento e a manutenção das entidades sindicais existentes na região, somada a estas, há, ainda, a necessidade da interpelação judicial para obstar a ocorrência da prescrição.

Conforme Delgado (2019, p. 1691-1692) relata:

A Lei da Reforma Trabalhista (n. 13.467, vigente desde 11.11.2017), também trouxe impactos na compreensão acerca da negociação coletiva trabalhista. Os objetivos da reforma, conforme se percebe, foram distintos. Em sua grande maioria, tais objetivos foram direcionados à diminuição do valor trabalho na economia e na sociedade brasileiras, com a elevação dos ganhos econômicos pelo sistema capitalista do País ao longo de seu manejo contratual da força de trabalho. Para tanto, foram perfilados diversos caminhos, porém convergentes: elevação do poder unilateral do empregador no interior do contrato de adesão empregatício; enfraquecimento da imperatividade das regras jurídicas trabalhistas; exacerbação dos poderes da negociação coletiva trabalhista, mas na direção da flexibilização de regras, garantias e direitos fixados em lei; enfraquecimento do sindicalismo de trabalhadores no País. Todos esses caminhos afetam, direta ou indiretamente, os poderes e limites da negociação coletiva trabalhista (limites que foram gravemente atenuados, como já referido neste Curso). Por intermédio do novo art. 611-A da CLT foram explicitados os vários temas sobre os quais a negociação coletiva do trabalho pode atuar (naturalmente, com a participação do sindicato profissional correspondente e por meio de Cactos ou Cates) - e, relativamente a esses temas, as cláusulas negociais coletivas "têm prevalência sobre a lei" (caput do art. 611-A da CLT).

\subsection{A REDUÇÃO DO NÚMERO DE CASOS NOVOS NO RITO ORDINÁRIO (RO) DO ANO DE 2017 PARA 2018 E A SUA CONSTÂNCIA EM 2019}

Neste item, pretende-se apresentar os dados e a análise dos possíveis dispositivos legais, criados ou modificados pela Reforma Trabalhista, aptos a influírem na variação da dinâmica processual do Rito Ordinário.

Relendo os motivos expostos no Projeto de Lei no $6.787 / 2016^{7}$, o qual foi a base para a criação da Lei no 13.467/2019 (Lei da Reforma Trabalhista), em seu item7, é mencionado que, no Brasil, há um nível elevado de judicialização das relações de trabalho, retratado, assim, a expressiva quantidade de demandas existentes somados aos novos casos, por essas e outras razões, devem ser qualificados os canais institucionais de

\footnotetext{
${ }^{7}$ https://www2.camara.leg.br/atividade-legislativa/discursos-e-notas-taquigraficas/discursos-emdestaque/projeto-de-lei-no-6787-2016-reforma-trabalhista/projeto-de-lei-no-6787-2016-reformatrabalhista-1
} 
diálogo entre empresário e trabalhador, como um provável fator de redução de novas ações judiciais trabalhistas.

O citado item, atrelado a outros do mesmo documento, expõe a necessidade do aprimoramento institucional das negociações em vista da regulamentação do art. $11^{8}$ da CF/1988, apurando-se a autonomia das partes envolvidas nas relações de emprego e a auto composição do conflito trabalhistas. Nessa linha, as várias empresas com mais de 200 empregados localizadas nos municípios que são abrangidos pela jurisdição da Vara do Trabalho de Santa Maria estariam cumprindo o citado artigo, desse modo, constituíram os representantes de empresas? Retomando a pesquisa de campo, buscou-se saber, via sindicatos, quantas comissões de representações de empregados foram criadas após a entrada em vigor da reforma, nos termos do artigo 510-A $-\mathrm{D}$, e, como resposta, descobriu-se que possuem várias empresas com mais de 200 funcionários, mas nenhuma delas criou a citada comissão de representantes.

A reforma tem continuidade com a PL 6787/2016, depois PL 38/2017, e quando da exposição de seus motivos destaca:

[...] a modernização das leis trabalhistas também será importante para conter o avanço dessa excessiva busca pelo Judiciário para solução dos conflitos entre as partes, pautando não só o desestímulo ao ativismo judicial, mas criando mecanismos que estimulem a solução desses conflitos antes que seja necessário submetê-los ao Poder Judiciário. E aqui não estamos falando em se impedir o acesso ao Judiciário, direito garantido plenamente pela Constituição Federal, mas em se privilegiar as soluções extrajudiciais na composição dos conflitos (BRASIL, 2016, p. 24).

A não criação de tais comissões conduziria em elevação do número de novos conflitos na Justiça do Trabalho?

Assim, a redução de 990 para 402 novas ações distribuídas sob o rito ordinário nos anos de 2017 para 2018 e sua constância em 2019, como destacado no Gráfico 4, não pode ser compreendida ou impactada pela regulamentação do art. 11 da CF/88 e artigo 510-A da CLT.

\footnotetext{
8 "Art. 11. Nas empresas de mais de duzentos empregados, é assegurada a eleição de um representante destes com a finalidade exclusiva de promover-lhes o entendimento direto com os empregadores." (BRASIL, 1988, online).

9 "Art. 510-A. Nas empresas com mais de duzentos empregados, é assegurada a eleição de uma comissão para representá-los, com a finalidade de promover-lhes o entendimento direto com os empregadores. (Incluído pela Lei no 13.467, de 2017).” (BRASIL, 1943, online).
} 
Efeitos da reforma trabalhista na justiça do trabalho: análise da dinâmica processual na segunda vara do trabalho de Santa Maria/RS

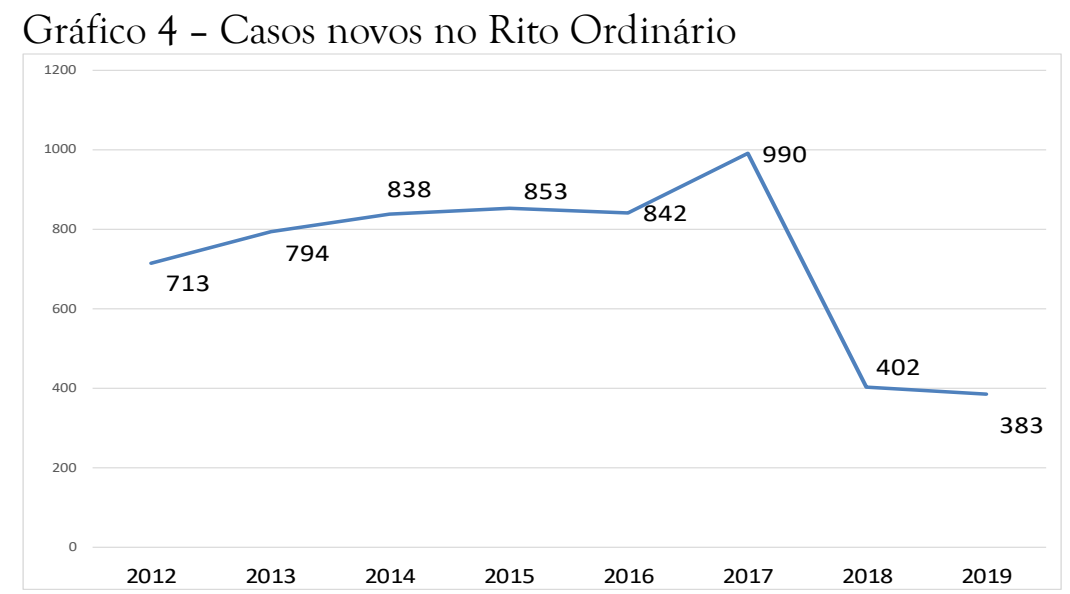

Fonte: Dados secundários acessados via sistema do PJe - TRT4.

Pela leitura do Gráfico 4, é preciso pontuar que, no ano de 2019, houve um declínio do número de novas ações no rito ordinário, sem que essa diminuição gerasse aumento no número de ações no rito sumaríssimo. É possível inferir que certa quantidade de ações migrou do RO para o rito sumaríssimo?

A Reforma Trabalhista obstaculizou o acesso $^{10}$ à justiça do trabalho aos reclamantes, em sua maioria ex-empregados ou desempregados, regrando um sistema de custas para o ingresso com novas ações, somadas às custas como condição e ou sanção de ingresso ou reingresso ${ }^{11}$ judicial em algumas situações. ${ }^{12-13}$

Revelando-se um sistema mais rígido e obstativo que o já existente para as demandas propostas na Justiça Comum Estadual ou Federal, desse modo, tais ajustes criaram barreiras, por vezes intransponíveis e inconstitucionais, aos que buscam restaurar o direito material violado, um fator apto a servir como explicação a redução do número de novas ações no rito ordinário.

${ }^{10}$ Enunciado no 103 (ANAMATRA, 2020).

${ }^{11}$ Enunciado no 25 (ANAMATRA, 2020).

${ }^{12} \mathrm{~A}$ parte sucumbente na ação e/ou no objeto de perícia é responsável pelo pagamento das custas e dos honorários periciais, ainda que beneficiária da justiça gratuita.Art. 790-B da CLT: A responsabilidade pelo pagamento dos honorários periciais é da parte sucumbente na pretensão objeto da perícia, ainda que beneficiária da justiça gratuita. (Redação dada pela Lei no 13.467 , de 2017). TRT da 4a Região / PROCESSO no 0021943-51.2016.5.04.0204 (RO) / RECORRENTE: MARIO OZI OLIVEIRA ALEGRE / RECORRIDO: U T C ENGENHARIA S/A - EM RECUPERAÇÃO JUDICIAL, PETRÓLEO BRASILEIRO S A PETROBRAS / RELATOR: MANUEL CID JARDON / EMENTA / HONORÁRIOS PERICIAIS E ADVOCATÍCIOS. AJUIZAMENTO DA AÇÃO ANTERIOR À LEI No 13.467/2017. Indevidos honorários periciais e honorários advocatícios pelo reclamante, em face de ajuizamento de reclamatória trabalhista em data anterior a vigência da Lei n. 13.467/2017. Acórdão: 0021943-51.2016.5.04.0204 (RO) / Redator: MANUEL CID JARDON / Órgão julgador: 1ª Turma /Data: 08/11/2018

${ }^{13}$ Sem contar a discussão de (in) constitucionalidade dos arts. 789 e 790-B da CLT no STF (artigos modificados pela Lei no ${ }^{\circ}$ 13.467/2017 - Reforma Trabalhista). 
Nos termos do artigo $789^{14}$ da CLT, o benefício da justiça gratuita ${ }^{15}$ sofreu modificações mitigadoras em sua capacidade e abrangência processual pro misero. Os demandantes e os julgadores terão que se ater àqueles que percebem salário igual ou inferior a $40 \%$ do limite máximo dos benefícios do RGPS; exigiu-se a comprovação de certas condições sociais e econômicas, assim não basta alegar ou requerer a insuficiência de recursos para o não pagamento das custas. Não menos importante é o disposto no artigo $844^{16}$ da CLT, em que o não comparecimento do reclamante importa em arquivamento e condenação às custas ${ }^{17}$, ainda que beneficiário da justiça gratuita.

Além da dinâmica das custas processuais, a reforma normatizou o sistema das sucumbências, que inexistiam ou eram inaplicáveis aos trabalhadores, em sua maioria reclamantes, quando vindicavam na Justiça Laboral. A partir do disposto nos artigos citados abaixo, reclamante e reclamado, em caso de vencidos total ou parcialmente, terão de arcar com os custos de sua derrota (sucumbência).

Na mesma linha, foram normatizadas outras sucumbências ${ }^{18}$. A do artigo $790-B^{19}$ quanto à parte vencida na pretensão objeto da perícia $^{20}$, ainda que beneficiária da justiça gratuita. Ao advogado que, em causa própria, atua em juízo, serão devidos honorários sucumbenciais, recíprocos na ação principal e na reconvenção, nos termos do artigo 791-A. No depoimento das testemunhas que não souberem falar a língua nacional e

14 "Art. 789. Nos dissídios individuais e nos dissídios coletivos do trabalho, nas ações e procedimentos de competência da Justiça do Trabalho, bem como nas demandas propostas perante a Justiça Estadual, no exercício da jurisdição trabalhista, as custas relativas ao processo de conhecimento incidirão à base de $2 \%$ (dois por cento), observado o mínimo de $\mathrm{R} \$ 10,64$ (dez reais e sessenta e quatro centavos) e o máximo de quatro vezes o limite máximo dos benefícios do Regime Geral de Previdência Social [...]. $\S 3^{\circ}$. É facultado aos juízes, órgãos julgadores e presidentes dos tribunais do trabalho de qualquer instância conceder, a requerimento ou de ofício, o benefício da justiça gratuita, inclusive quanto a traslados e instrumentos, àqueles que perceberem salário igual ou inferior a $40 \%$ (quarenta por cento) do limite máximo dos benefícios do Regime Geral de Previdência Social. [...] \& $4^{\circ}$. O benefício da justiça gratuita será concedido à parte que comprovar insuficiência de recursos para o pagamento das custas do processo." (BRASIL, 1943, online, grifo nosso).

${ }^{15}$ Enunciados no 27, 28, 29, 30, 31, 34 e 35 (ANAMATRA, 2020).

16“Art. 844 - O não-comparecimento do reclamante à audiência importa o arquivamento da reclamação, e o não-comparecimento do reclamado importa revelia, além de confissão quanto à matéria de fato. [...] $\S 2^{\circ}$. Na hipótese de ausência do reclamante, este será condenado ao pagamento das custas calculadas na forma do art. 789 desta Consolidação, ainda que beneficiário da justiça gratuita, salvo se comprovar, no prazo de quinze dias, que a ausência ocorreu por motivo legalmente justificável. $\S 3^{\circ}$. $\mathrm{O}$ pagamento das custas a que se refere o $\S 2^{\circ}$ é condição para a propositura de nova demanda." (BRASIL, 1943, online, grifo nosso).

${ }^{17}$ Enunciado no 26 (ANAMATRA, 2020).

${ }^{18}$ Enunciados $n^{\circ}$ 33, 98, 99 (ANAMATRA, 2020).

19 "Art. 790-B. A responsabilidade pelo pagamento dos honorários periciais é da parte sucumbente na pretensão objeto da perícia, ainda que beneficiária da justiça gratuita. [...] $\S 4^{\circ}$. Somente no caso em que o beneficiário da justiça gratuita não tenha obtido em juízo créditos capazes de suportar a despesa referida no caput, ainda que em outro processo, a União responderá pelo encargo." (BRASIL, 1943, online, grifo nosso).

${ }^{20}$ Enunciado 31 (ANAMATRA, 2020). 
Efeitos da reforma trabalhista na justiça do trabalho: análise da dinâmica processual na segunda vara do trabalho de Santa Maria/RS

dependam mediação por interprete, as despesas deste recairão na parte sucumbente, como normado pelo artigo $819^{21}$ da CLT.

Nos citados artigos, há vários tipos sucumbências: pericial, advocatícia da ação principal, advocatícia da reconvenção e do intérprete, entre outros. Esse aparato sucumbencial criado, em parte, pela reforma, é um alerta financeiro sancionatório aos profissionais do direito (advogados) e à parte reclamante, apto a criar uma expectativa de perdas, sanções, custos e riscos relativamente altos, quando confrontado com o sistema judicial de acesso à justiça laboral revogado pela reforma trabalhista.

Desse modo, a redução do número de novas ações no RO pode ter sido gerada, em parte, pelo somatório dessas sucumbências ao vencido.

Nos idos de 2016, a integralidade das custas e das despesas sucumbenciais alcançavam minimamente o trabalhador/reclamante e, quando ocorriam, eram fulminadas pelo benefício da justiça gratuita. O citado benefício ainda continua existindo, viabilizando o acesso à justiça enquanto uma prerrogativa constitucional de cidadania, mas a sua eficácia jurídica para as partes declaradamente pobres e hipossuficientes foi mitigada.

A reforma criou um sistema diferenciado para o ingresso com novas ações a partir das novas exigências formais à Petição Inicial do rito ordinário e/ou trouxe para o referido rito as exigências já definidas para o rito sumário e sumaríssimo quanto à certeza, determinação e indicação do valor de cada pedido nos termos do artigo $840^{22}$ da CLT.

A exigência da determinação e do valor dos pedidos elados ao pagamento das custas ou da condenação ao pagamento desta pelo vencido, assim como a possibilidade real de condenação em valores sucumbenciais (honorários e periciais) ao final da ação, somados aos longos anos para uma solução, nem sempre, efetiva da demanda judicial, entre outros fatores, criou obstáculos reais para um grande número de novas demandas judiciais. Às novas ações trabalhistas fora ainda imposto um crivo técnico jurídico e contábil mais apurado, pois passaram a ser revistas ou revestidas de maior formalismo legal, o que, para alguns cientistas jurídicos, mitigou os direitos laborais e o acesso à justiça. No atual sistema judicial laboral, a parte reclamante corre os riscos reais de, ao final do processo, ser vencida e, com isso, onerar-se para além de seus créditos.

21 “Art. 819 - O depoimento das partes e testemunhas que não souberem falar a língua nacional será feito por meio de intérprete nomeado pelo juiz ou presidente. [...] \& $2^{\circ}$ As despesas decorrentes do disposto neste artigo correrão por conta da parte sucumbente, salvo se beneficiária de justiça gratuita." (BRASIL, 1943, online, grifo nosso).

22،Art. 840 - A reclamação poderá ser escrita ou verbal. § 1. Sendo escrita, a reclamação deverá conter a designação do juízo, a qualificação das partes, a breve exposição dos fatos de que resulte o dissídio, o pedido, que deverá ser certo, determinado e com indicação de seu valor, a data e a assinatura do reclamante ou de seu representante. [...] § 30. Os pedidos que não atendam ao disposto no $\S 1$ o deste artigo serão julgados extintos sem resolução do mérito." (BRASIL, 1943, online, grifo nosso). 
$\mathrm{Na}$ mesma linha, é preciso antever que, na maioria das vezes, o reclamante, quando do ingresso com a reclamatória trabalhista, não está guarnecido dos documentos necessários para a determinação e ou indicação do quantum que pretende vindicar. Desse modo, que grau de certeza esses cálculos iniciais terão quando do ingresso, quando realizados, muitas vezes, distantes da realidade documental do contrato de trabalho e, salvo melhor perícia, tais valores serão indicados na inicial a menor para que os efeitos da condenação sucumbencial não afetem os créditos que porventura serão providos.

Não são raros os casos em que a carteira de trabalho é entregue ao trabalhador na própria audiência. $\mathrm{O}$ caminho trilhado por alguns patronos é ingressar com uma ação cautelar de exibição de documentos em desfavor do reclamado para que a inicial trabalhista possa ser adequadamente instruída. Assim, na dúvida, não formule o pedido; na dúvida, peça o mínimo; na dúvida, não ingresse na Justiça do Trabalho, dúvidas tais e tantas que podem ter obstado o nascimento de novas ações.

Outro ponto que merece atenção é a taxatividade atribuída ao valor da indenização pela ocorrência do dano extrapatrimonial (moral, existencial, etc.), como definido no artigo 223- $\mathrm{A}^{23}$ e letras seguintes, que mitigou a intenção de vultuosidade das pretensões financeiras requeridas pelos reclamantes em juízo sob esta pretensão (RAMOS; GALIA, 2019, p. 246).

Nas rotinas processuais trabalhistas, antes da reforma, eram comuns causas com valores de 100 mil, 200 mil, 500 mil, 1 milhão ou mais tramitarem sem que a parte reclamante estivesse atenta às custas e à sucumbência que seria condenada a pagar se vencida, e um dos pedidos que elevava o valor das causas era o quantum indenizatório do Dano Extrapatrimonial sofrido. Por vezes, na primeira audiência, quando o magistrado informava as partes da possibilidade de conciliação, acordos eram entabulados em

23 “Art. 223-A. Aplicam-se à reparação de danos de natureza extrapatrimonial decorrentes da relação de trabalho apenas os dispositivos deste Título. [...] Art. 223-G. Ao apreciar o pedido, o juízo considerará: I - a natureza do bem jurídico tutelado; II - a intensidade do sofrimento ou da humilhação; III - a possibilidade de superação física ou psicológica; IV - os reflexos pessoais e sociais da ação ou da omissão; V - a extensão e a duração dos efeitos da ofensa; VI - as condições em que ocorreu a ofensa ou o prejuízo moral; VII - o grau de dolo ou culpa; VIII - a ocorrência de retratação espontânea; IX - o esforço efetivo para minimizar a ofensa; X - o perdão, tácito ou expresso; XI - a situação social e econômica das partes envolvidas; XII - o grau de publicidade da ofensa. § $1^{\circ}$. Se julgar procedente o pedido, o juízo fixará a indenização a ser paga, a cada um dos ofendidos, em um dos seguintes parâmetros, vedada a acumulação: I - ofensa de natureza leve, até três vezes o último salário contratual do ofendido; II - ofensa de natureza média, até cinco vezes o último salário contratual do ofendido; III - ofensa de natureza grave, até vinte vezes o último salário contratual do ofendido; IV - ofensa de natureza gravíssima, até cinquenta vezes o último salário contratual do ofendido. $\S 2^{\circ}$. Se o ofendido for pessoa jurídica, a indenização será fixada com observância dos mesmos parâmetros estabelecidos no $\S 1$ lo deste artigo, mas em relação ao salário contratual do ofensor. $\S 3^{\circ}$. Na reincidência entre partes idênticas, o juízo poderá elevar ao dobro o valor da indenização." (BRASIL, 1943, online, grifo nosso). 
Efeitos da reforma trabalhista na justiça do trabalho: análise da dinâmica processual na segunda vara do trabalho de Santa Maria/RS

valores aquém a $10 \%$ ou $5 \%$ da pretensão financeira posta na inicial, o que se revelava inconsistente e dúbio.

A tentativa de enriquecimento com ou sem causa tornavam a justiça do trabalho, para alguns juristas, um "balcão de apostas", geradoras do já citado "demandismo judicial trabalhista" ou "aventuras judiciais". ${ }^{24}$

A taxatividade do dano moral, do assédio, que, sob certa perspectiva é considerada inconstitucional, limitou a possibilidade de majoração expressiva das ações propostas após a entrada em vigor da reforma trabalhista, fato este capaz de conduzir parte das novas ações ao rito sumaríssimo. Essa norma é capaz de representar um dos fatores preponderantes no rebaixamento do valor das novas ações e a consequente migração entre os ritos.

A implantação do PJe pode ser outro fator capaz de gerar obstáculo ao acesso à justiça, para uma minoria de trabalhadores que buscariam acessá-la fazendo uso do jus postulandi. $\mathrm{Na}$ mesma linha, o PJe onerou a estrutura administrativa e funcional dos profissionais do direito (advogados e escritórios) em vista da exigência de novos computadores, sistemas de assinatura digital, monitores, e houve uma elevação no custo tecnológico e informacional, tais custos podem estar sendo mais uma das barreiras de

\footnotetext{
${ }^{24}$ TST - Porteiro que perdeu ação contra a UFRN deve pagar honorários advocatícios: $\mathrm{O}$ desconto incidirá sobre todos os créditos, e não apenas os de natureza não alimentícia. A Quarta Turma do Tribunal Superior do Trabalho deferiu o pagamento de honorários advocatícios à Universidade Federal do Rio Grande do Norte, a serem descontados dos créditos trabalhistas que venham a ser obtidos por um porteiro beneficiário da justiça gratuita. A decisão reforma o entendimento do Tribunal Regional do Trabalho da 21a Região (RN), que restringia o desconto aos créditos de natureza não alimentícia. Contratado pela Safe Locação de Mão de Obra e Serviços Ltda. para trabalhar na Faculdade de Ciências da Saúde (Facisa) da UFRN, o porteiro ajuizou a reclamação contra o empregador e a tomadora dos serviços. O pedido foi julgado procedente apenas em relação à empresa, com o deferimento de parte das parcelas pleiteadas pelo empregado. A UFRN, então, recorreu ao TRT para requerer o pagamento dos honorários advocatícios, pois o porteiro havia perdido a ação em relação a ela. O TRT deferiu a pretensão e condenou o trabalhador ao pagamento mínimo de 5\% sobre o valor da condenação. Determinou, no entanto, que o percentual deveria incidir apenas sobre os créditos de natureza não alimentar devidos ao porteiro na reclamação ou em outro processo eventualmente em trâmite na Justiça do Trabalho. Honorários sucumbenciais - Os chamados honorários advocatícios sucumbenciais são a parcela devida pela parte perdedora na ação. De acordo com o artigo 791-A, parágrafo 4º da CLT, introduzido pela Reforma Trabalhista (Lei 13.467/2017), caso a parte vencida seja beneficiária da justiça gratuita, as obrigações decorrentes da sucumbência ficam suspensas e somente podem ser executadas se, nos dois anos subsequentes ao esgotamento das possibilidades de recurso (trânsito em julgado), o credor demonstrar que deixou de existir a situação que havia justificado a concessão de gratuidade. Caso isso não ocorra, as obrigações são extintas. Natureza alimentar - O relator do recurso de revista da UFRN, ministro Ives Gandra, assinalou que o TRT, ao condicionar o pagamento à existência de créditos de natureza não alimentícia, ampliou a cautela prevista na lei "ao ponto de praticamente inviabilizar" o recebimento dos honorários advocatícios por parte do empregador vencedor. "A cautela adicional e sem base legal, no caso de demanda trabalhista, representa praticamente negar o direito do empregador vencedor, na medida em que os créditos judiciais trabalhistas são, por natureza, alimentares", afirmou. A decisão foi unânime. Processo: RR-780-77.2017.5.21.0019. Fonte: Tribunal Superior do Trabalho.
} 
acesso à justiça trabalhista, quando aquele for repassado aos novos e futuros clientes ou quando forem sopesados em relação às causas de pequena monta.

A tecnificação gerada pela implantação da plataforma eletrônica de processos, sob a perspectiva dos advogados que já atuavam há décadas com os processos físicos, foi percebida, em parte, como um motivo para a aposentadoria. A complexidade do sistema eletrônico, a ausência do manuseio físico do papel, entre outras narrativas, conduziram ao abandono da atividade laborativa por parte de alguns profissionais, e, em consequência, algumas carteiras já estruturadas de clientes trabalhistas deixaram de ser, em parte, atendidas.

A reforma normatizou a rescisão do contrato de trabalho pela via do acordo entre empregado e empregador, nos termos do artigo 484-A ${ }^{25}$. É possível que uma parte dos contratos de trabalho extintos por acordo, após a entrada em vigor da reforma trabalhista, tenham sido rescindidos de forma adequada. $\mathrm{O}$ valor que o ex-empregado recebe como resultado dessa modalidade de extinção dos contratos de emprego cria uma possibilidade imediata e consensual de rescisão, facultando ou dispensando, por vezes, o ingresso na justiça do trabalho. É notório o fato, para os profissionais da área trabalhista, que empregador e empregado ajustavam, antes da entrada em vigor da reforma trabalhista, a modalidade de rescisão do contrato de trabalho, muitas vezes, elados em desfavor do Estado.

A desnecessidade da assistência homologatória sindical ${ }^{26}$ às rescisões dos contratos de emprego é outro fator importantíssimo na redução do número de novas ações trabalhistas. A reforma dispensou a exigência da participação sindical, aumentando o distanciamento entre empregado de sua entidade de classe profissional. Tal alteração legislativa mitigou o acesso à informação por parte deste ex-empregado tomar ciência das violações praticadas pelo ex-empregador, quando da existência do contrato de trabalho, o que precariza as chances de ingresso na justiça do trabalho. Era

\footnotetext{
25“Art. 484-A. O contrato de trabalho poderá ser extinto por acordo entre empregado e empregador, caso em que serão devidas as seguintes verbas trabalhistas: I - por metade: a) o aviso prévio, se indenizado; e b) a indenização sobre o saldo do Fundo de Garantia do Tempo de Serviço, prevista no § 1o do art. 18 da Lei no 8.036, de 11 de maio de 1990; II - na integralidade, as demais verbas trabalhistas. $\$ 1^{\circ}$. A extinção do contrato prevista no caput deste artigo permite a movimentação da conta vinculada do trabalhador no Fundo de Garantia do Tempo de Serviço na forma do inciso I-A do art. 20 da Lei no 8.036, de 11 de maio de 1990, limitada até 80\% (oitenta por cento) do valor dos depósitos. $§ 2^{\circ}$. A extinção do contrato por acordo prevista no caput deste artigo não autoriza o ingresso no Programa de Seguro-Desemprego.” (BRASIL, 1943, online, grifo nosso).

26“Art. 477. Na extinção do contrato de trabalho, o empregador deverá proceder à anotação na Carteira de Trabalho e Previdência Social, comunicar a dispensa aos órgãos competentes e realizar o pagamento das verbas rescisórias no prazo e na forma estabelecidos neste artigo. \$ 10. O pedido de demissa recibo de quitação de rescisão, do contrato de trabalho, firmado por empregado com mais de 1 (um) ano de serviço, só será válido quando feito com a assistência do respectivo Sindicato ou perante a autoridade do Ministério do Trabalho e Previdência Social. (Redação dada pela Lei no 5.584/70) [...] $\S 1^{\circ}$. (Revogado pela Lei no 13.467/2017).” (BRASIL, 1943, online, grifo nosso).
} 
Efeitos da reforma trabalhista na justiça do trabalho: análise da dinâmica processual na segunda vara do trabalho de Santa Maria/RS

costume dos agentes sindicais ressalavar no verso do Termo de Rescisão do Contrato de Trabalho as verbas ou prestações inadimplidas ou irregularmente adimplidas, o que conduzia o trabalhador a demandar por tais pretensões.

O normado pelo artigo 477-B ${ }^{27}$ da CLT em relação aos Planos de Demissão Voluntária (PDVs) também gerou um efeito obstativo ao nascimento de novas ações trabalhistas.

A Orientação Jurisprudencial da Seção de Dissídios Individuais 1 já normava o PDV da seguinte forma:

OJ-SDI1-270 PROGRAMA DE INCENTIVO A
VOLUNTÁRIA. TRANSACCÃO
ORIUNDAS DO EXTINTO CONTRATO DE TRABALHO. EFEITOS
(inserida em 27.09.2002) - A transação extrajudicial que importa rescisão do
contrato de trabalho ante a adesão do empregado a plano de demissão
voluntária implica quitação exclusivamente das parcelas e valores constantes
do recibo.

A jurisprudência do Tribunal Superior do Trabalho (TST) vem julgando as lides a partir do seguinte precedente:

TST PROGRAMA DE DEMISSÃO VOLUNTÁRIA.
REPERCUSSÃO GERAL - RE-590.415/SC. AUSENCIA DE EXPRESSA
DISPOSIÇÃO NO ACORDO COLETIVO DE QUITAÇÃO AMPLA E
IRRESTRITA. O Tribunal Regional, soberano na análise do conjunto fático e
probatório, consignou que "não consta nos autos que tenha havido
negociação coletiva aprovadora dos termos do PDV, autorizando
a quitação ampla e irrestrita de todas as parcelas objeto do contrato de
emprego". Assim, não há se falar em aplicar o entendimento do STF, ocorrido
em repercussão geral, ante a ausência de expressa disposição no acordo
coletivo de quitação ampla e irrestrita. Por outro lado, consta do acórdão
regional que, "embora o termo de transação faça menção de quitação de
inúmeras verbas, não constam especificados os valores remunerados a tais
títulos, havendo somente referência ao total pago pela adesão do autor ao
PDV". Dessa forma, a Corte de Origem verificou que o PDV englobou
genericamente inúmeras verbas trabalhistas, conferindo quitação plena
e geral de todos os efeitos do contrato de trabalho. Nesse contexto, a decisão
regional que concluiu ser inválida a quitação genérica das parcelas está em
conformidade com a Orientação Jurisprudencial no 270 da SBDI-1 do TST.
Agravo conhecido e não provido.

Já o Supremo Tribunal Federal (STF) entende que os PDVs:

\footnotetext{
27“Art. 477-B. Plano de Demissão Voluntária ou Incentivada, para dispensa individual, plúrima ou coletiva, previsto em convenção coletiva ou acordo coletivo de trabalho, enseja quitação plena e irrevogável dos direitos decorrentes da relação empregatícia, salvo disposição em contrário estipulada entre as partes." (BRASIL, 1943, online, grifo nosso).
} 
STF - EMENTA: AGRAVO REGIMENTAL EM RECURSO EXTRAORDINÁRIO COM AGRAVO. PROGRAMA DE DEMISSÃO VOLUNTÁRIA. QUITAC̣ÃO. EFEITOS. SÚMULA 279, DO STF. 1. A jurisprudência dominante do STF assentou que "a transação judicial que importa rescisão do contrato de trabalho, em razão de adesão voluntária do empregado ao plano de dispensa voluntária, enseja quitação ampla e irrestrita de todas as parcelas objeto do contrato de emprego, caso essa condição tenha constado expressamente em acordo coletivo que aprovou o plano, bem como dos demais instrumentos celebrados com o empregado" (RE 590.415/SC). 2. No presente caso, o tribunal de origem decidiu que não há registro acerca da existência de cláusula coletiva prevendo expressamente a quitação geral do contrato de trabalho em face da adesão do empregado ao PDV. 3. Para se chegar à conclusão diversa daquela a que chegou o juízo a quo, seria necessário o reexame de fatos e provas, possibilidade obstada pela Súmulas 279 do STF. 4. Agravo regimental a que se nega provimento, com aplicação da multa prevista no art. 1.021, §4, CPC. (ARE $1167163 \mathrm{AgR}$, Relator(a): Min. EDSON FACHIN, Segunda Turma, julgado em 24/06/2019, PROCESSO ELETRÔNICO DJe-167 DIVULG 31-07-2019 PUBLIC 01-08-2019)

A efetivação dos Planos de Demissão Voluntária seguindo os rigores legais tornase um instrumento que irá obstar o ajuizamento de novas ações trabalhistas.

A par dele, há ainda o termo de quitação anual nos termos do artigo 507-B ${ }^{28}$ da CLT, que irá também servir como instrumento mitigador de novas ações, mesmo tendo ele eficácia liberatória específica.

O Gráfico 5 não permite afirmar que houve migração das novas ações do RO para o RS, mas parte das demandas, as quais a pesquisa quantitativa não conseguiu destacar, podem ter migrado, em vista da análise legislativa, até então, desenvolvida.

28 "Art. 507-B. É facultado a empregados e empregadores, na vigência ou não do contrato de emprego, firmar o termo de quitação anual de obrigações trabalhistas, perante o sindicato dos empregados da categoria. (Incluído pela Lei no 13.467, de 2017). Parágrafo único. O termo discriminará as obrigações de dar e fazer cumpridas mensalmente e dele constará a quitação anual dada pelo empregado, com eficácia liberatória das parcelas nele especificadas. (Incluído pela Lei n 13.467 , de 2017)." (BRASIL, 1943, online, grifo do autor). 
Efeitos da reforma trabalhista na justiça do trabalho: análise da dinâmica processual na segunda vara do trabalho de Santa Maria/RS

Gráfico 5 - Casos novos Rito Ordinário e Sumaríssimo

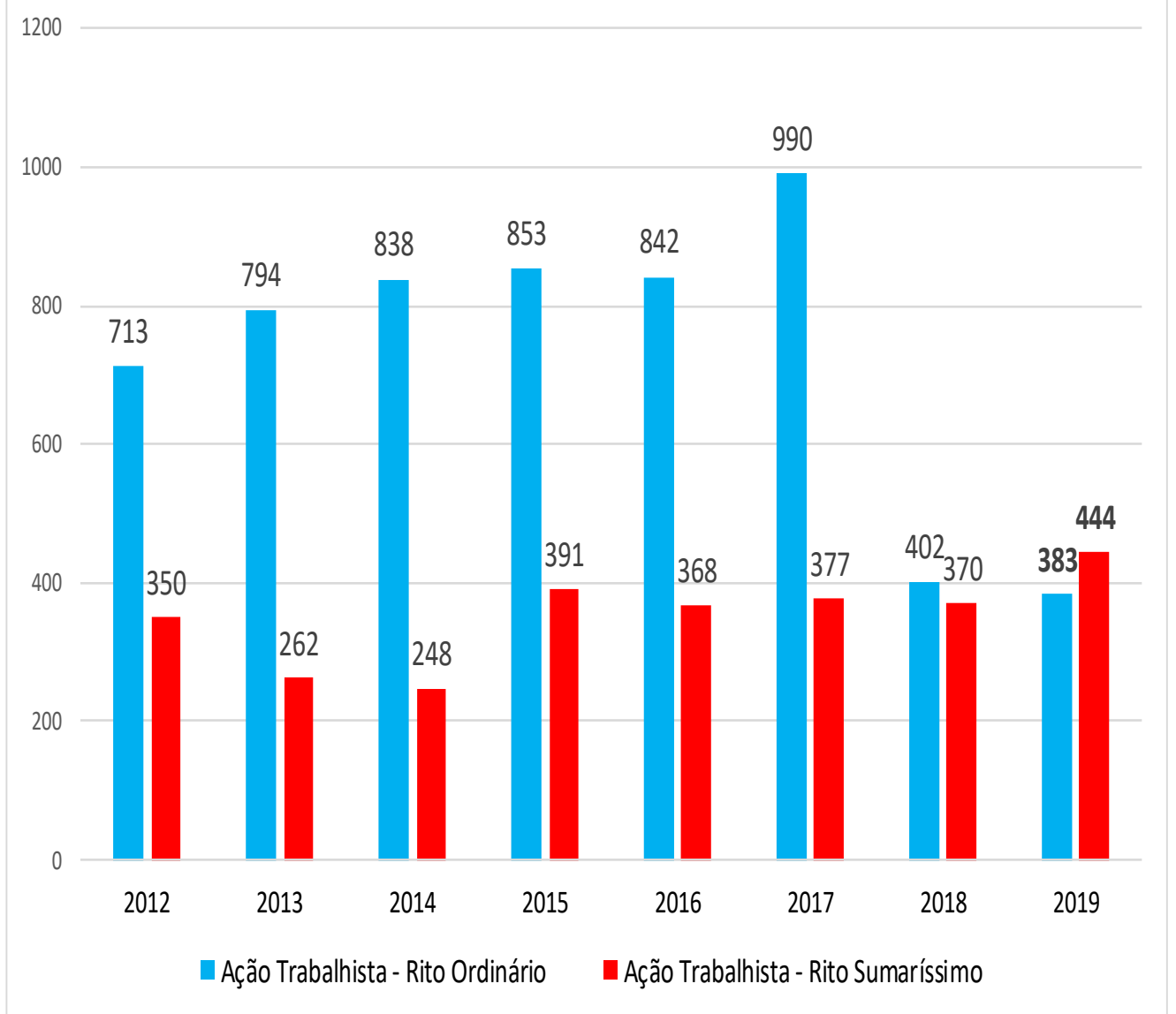

Fonte: dados secundários acessados via sistema do PJe - TRT4.

Vê-se claramente que o número de ações nas barras em vermelho (rito sumaríssimo) se manteve em uma variável entre 350 a 409 casos por ano. Quando, em outubro de 2019, atinge a marca histórica de 444 ações, ultrapassando, pela primeira vez, o número de novos casos distribuídos no RO. Ao passo que, se as ações ordinárias tivessem migrado, em grau elevado, para o rito sumaríssimo, teríamos um impacto dessas ações já em 2018, forçando a elevação do número de ações no rito sumaríssimo para além dos números apresentados, mas os dados não revelam tal ocorrência.

É de se observar que, em 2014, tem-se a implantação do PJe, acontecimento jurídico capaz, mas não isoladamente, de ter contribuído para que, naquele ano, as demandas adstritas ao rito sumaríssimo decrescessem.

Persiste a dúvida! Para onde foram ou onde foram propostas, se foram, as mais de 500 ações trabalhistas sob o rito ordinário em 2018? Infere-se que parte, não expressiva, das ações ordinárias tornaram-se sumaríssimas; infere-se que parte das ações sumaríssimas também deixaram de ser propostas, mesmo que o gráfico aponte a sua elevação; outra parte das ações ordinárias podem ter sido deixadas de ser propostas em vista das custas e dos riscos gerados pela reforma, somados a outros fatores que a 
abordagem quantitativa não permite inferir, o que demandaria mais uma etapa de pesquisa de campo fora da Vara do Trabalho.

Por outra via, o rito sumaríssimo, mesmo com suave elevação no número de novas ações em 2019 e leve baixa em 2018, pode ter também sofrido redução, em vista de que existiam pretensões que corriam o risco de serem julgadas total ou parcialmente improcedentes, impondo a estas riscos sucumbenciais e custas processuais. Assim, julgase oportuno concluir que ambos os ritos tiveram quedas no número geral de ações, mas o rito sumaríssimo teve a estrutura de absorver parte das ações antes propostas no rito ordinário, em vista da mitigação de alguns ímpetos vindicatórios e da mudança na dinâmica processual trabalhista a partir da entrada em vigor da reforma trabalhista que empurraram o valor das ações para baixo.

A mudança normativa gerada pela reforma revitalizou o rito sumaríssimo, logo terá o condão de gerar o mesmo efeito no esquecido rito sumário, os quais serão tratados a posteriori.

A Responsabilidade por Danos Processuais normado pela reforma, trazendo às partes e às testemunhas um conjunto de sanções aptas a gerar, por vezes, um receio e um obstáculo ao nascimento de novas ações na Justiça do Trabalho nos termos do artigo 793-A ${ }^{29}$ e seguintes.

É importante analisar o artigo 793-D, que estende a multa para as testemunhas que intencionalmente alterarem a verdade dos fatos, somada a ela, ainda há o tipo penal definido no art. 342 do Código Penal que classifica como crime de reclusão a afirmação falsa, a negação ou silêncio em relação aos fatos inquiridos. Desse modo, houve uma majoração qualificada das punições impostas para a testemunha que for convidada a informar a realidade laboral vivida pelo reclamante ou praticada pela reclamada.

\footnotetext{
29“Art. 793-A. Responde por perdas e danos aquele que litigar de má-fé como reclamante, reclamado ou interveniente. Art. 793-B. Considera-se litigante de má-fé aquele que: I - deduzir pretensão ou defesa contra texto expresso de lei ou fato incontroverso; II - alterar a verdade dos fatos; III - usar do processo para conseguir objetivo ilegal; IV - opuser resistencia injustificada ao andamento do processo; $\mathrm{V}$ - proceder de modo temerário em qualquer incidente ou ato do processo; VI - provocar incidente manifestamente infundado; VII - interpuser recurso com intuito manifestamente protelatório. Art. 793-C. De ofício ou a requerimento, o juízo condenará o litigante de má-fé a pagar multa, que deverá ser superior a $1 \%$ (um por cento) e inferior a $10 \%$ (dez por cento) do valor corrigido da causa, a indenizar a parte contrária pelos prejuízos que esta sofreu e a arcar com os honorários advocatícios e com todas as despesas que efetuou. $\S 1^{\circ}$ Quando forem dois ou mais os litigantes de má-fé, o juízo condenará cada um na proporção de seu respectivo interesse na causa ou solidariamente aqueles que se coligaram para lesar a parte contrária. § 2० Quando o valor da causa for irrisório ou inestimável, a multa poderá ser fixada em até duas vezes o limite máximo dos benefícios do Regime Geral de Previdência Social. § 30 O valor da indenização será fixado pelo juízo ou, caso não seja possivel mensurá-lo, liquidado por arbitramento ou pelo procedimento comum, nos próprios autos. Art. 793-D. Aplica-se a multa prevista no art. 793-C desta Consolidação à testemunha que intencionalmente alterar a verdade dos fatos ou omitir fatos essenciais ao julgamento da causa. Parágrafo único. A execução da multa prevista neste artigo dar-se-á nos mesmos autos." (BRASIL, 1943, online, grifo nosso).
} 
Efeitos da reforma trabalhista na justiça do trabalho: análise da dinâmica processual na segunda vara do trabalho de Santa Maria/RS

Tais determinações elevam o grau de lisura aos cidadãos que, por ventura, buscarem acessar a tutela jurisdicional trabalhista, ampliando deveres e responsabilidades.

\subsection{A ELEVAÇÃO DO NÚMERO DE AÇÕES NO RITO SUMÁRIO EM 2019}

A Lei no $5.584 / 70^{30}$ cria o Rito Sumário para as ações de até 2 salário mínimos. O referido teto financeiro é um dos fatores que impôs a escassez do número de ações tramitando nesse rito, muitos profissionais acreditavam que o referido rito sumário já estivesse revogado, uma vez que há algumas correntes doutrinárias que ainda defendem tal ocorrência, no mais, somos adeptos à corrente de que a referida lei está em vigor, mesmo que seus enunciados tenham sido absorvidos, em parte, pelo rito sumaríssimo. Por outra via, o rito sumário passou a ganhar destaque a partir de 2018.

É expressivo o aumento no número de novas ações propostas até 31 de outubro de 2019, nos termos do Gráfico 6. Tal variação decorre, principalmente, de dois fatos indiretos: primeiro deles foi a retirada da compulsoriedade do imposto sindical disposto nos artigos 578 e 579 da CLT $^{31}$, tal mudança tornou inviável a manutenção de muitos sindicatos no país. As instituições que se mantiveram em funcionamento passaram a buscar outras fontes de arrecadação, e uma delas foi a busca das parcelas contributivas sindicais inadimplidas e ainda não alcançadas pela prescrição tributária.

\footnotetext{
30“Art. 14. Na Justiça do Trabalho, a assistência judiciária” a que se refere a Lei $\mathrm{n}^{\circ} 1.060$, de 5 de fevereiro de 1950, será prestada pelo Sindicato da categoria profissional a que pertencer o trabalhador. $\S 1^{\circ}$. A assistência é devida a todo aquele que perceber salário igual ou inferior ao dobro do mínimo legal, ficando assegurado igual benefício ao trabalhador de maior salário, uma vez provado que sua situação econômica não lhe permite demandar, sem prejuízo do sustento próprio ou da família. § $2^{\circ}$. A situação econômica do trabalhador será comprovada em atestado fornecido pela autoridade local do Ministério do Trabalho e Previdência Social, mediante diligência sumária, que não poderá exceder de 48 (quarenta e oito) horas. $§ 3^{\circ}$. Não havendo no local a autoridade referida no parágrafo anterior, o atestado deverá ser expedido pelo Delegado de Polícia da circunscrição onde resida o empregado." (BRASIL, 1970, online).

31 "Art. 578. As contribuições devidas aos sindicatos pelos participantes das categorias econômicas ou profissionais ou das profissões liberais representadas pelas referidas entidades serão, sob a denominação de contribuição sindical, pagas, recolhidas e aplicadas na forma estabelecida neste Capítulo, desde que prévia e expressamente autorizadas. Art. 579. O desconto da contribuição sindical está condicionado à autorização prévia e expressa dos que participarem de uma determinada categoria econômica ou profissional, ou de uma profissão liberal, em favor do sindicato representativo da mesma categoria ou profissão ou, inexistindo este, na conformidade do disposto no art. 591 desta Consolidação.” (BRASIL, 1943, online).
} 
Gráfico 6 - Casos novos Rito Sumário

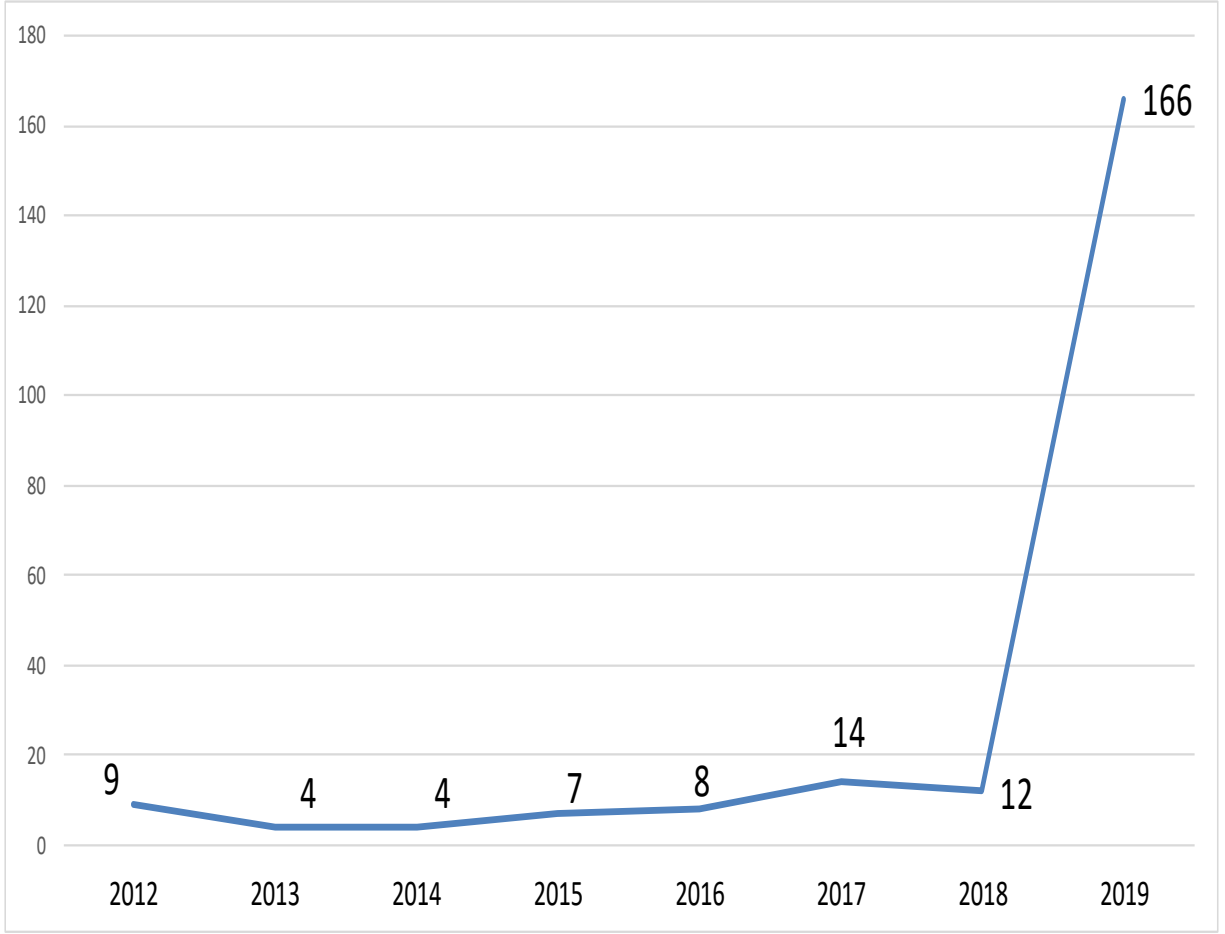

Fonte: dados secundários acessados via sistema do PJe - TRT4.

A elevação expressiva no número de ações no rito sumário no ano de 2019 foi resultado das demandas judiciais ajuizadas pelos sindicatos em desfavor de seus associados. Os pesquisadores retornaram à Vara do Trabalho em 22/11/2019 para analisar pormenorizadamente os feitos com o intuito de verificar as informações resultantes dos dados quantitativos, aptas a explicar a referida elevação.

Foram acessados 162 processos eletrônicos (de um total de 166), resultando:

160 eram novas ações propostas pelo Sindicato dos Corretores de Imóveis do Rio Grande do Sul - Ações de Cobrança (rito sumário) em desfavor dos corretores, para compeli-los ao pagamento da Contribuição Sindical referente aos exercícios dos anos de 2014, 2015, 2016 e $2017^{32}$;

02 eram novas ações propostas por Pessoas Físicas, ambas Reclamatórias Trabalhistas movidas contra ex-empregadores;

os demais (04) novas ações foram propostas após outubro de 2019, então fora do lapso temporal previamente definido para a construção deste artigo.

Depois de acessados os processos, é possível afirmar que não houve migração de ações do rito sumaríssimo para o rito sumário aptas a justificar tal elevação de 12 para 166 novos casos, pois o valor da causa atribuído à expressiva quantidade de ações de cobrança propostas no rito sumário não ultrapassa o valor de 2 salários mínimos.

${ }^{32} \mathrm{O}$ aumento de ações ocorreu porque um sindicato - o de corretores de imóveis - que há inclusive discussão quanto à existência ou não de vínculo empregatício, resolveu cobrar dos corretores de imóveis as anuidades sindicais. 
Efeitos da reforma trabalhista na justiça do trabalho: análise da dinâmica processual na segunda vara do trabalho de Santa Maria/RS

\subsection{A CONSTÂNCIA NO NÚMERO DE AÇÕES NO RITO SUMARÍSSIMO}

Para os profissionais da vara do trabalho, há clara tendência de que as ações que antes eram, em sua maioria, adstritas ao rito ordinário irem compor o rito sumaríssimo, em vista das mudanças normadas pela reforma. Infere-se que tanto o valor da causa tenha minorado como a quantidade de pedidos e seus desdobramentos tenham também sido afetados, reduzindo-se a complexidade das demandas e, com isso, apurando-se o desfecho das ações em novos prazos, agora mais exíguos.

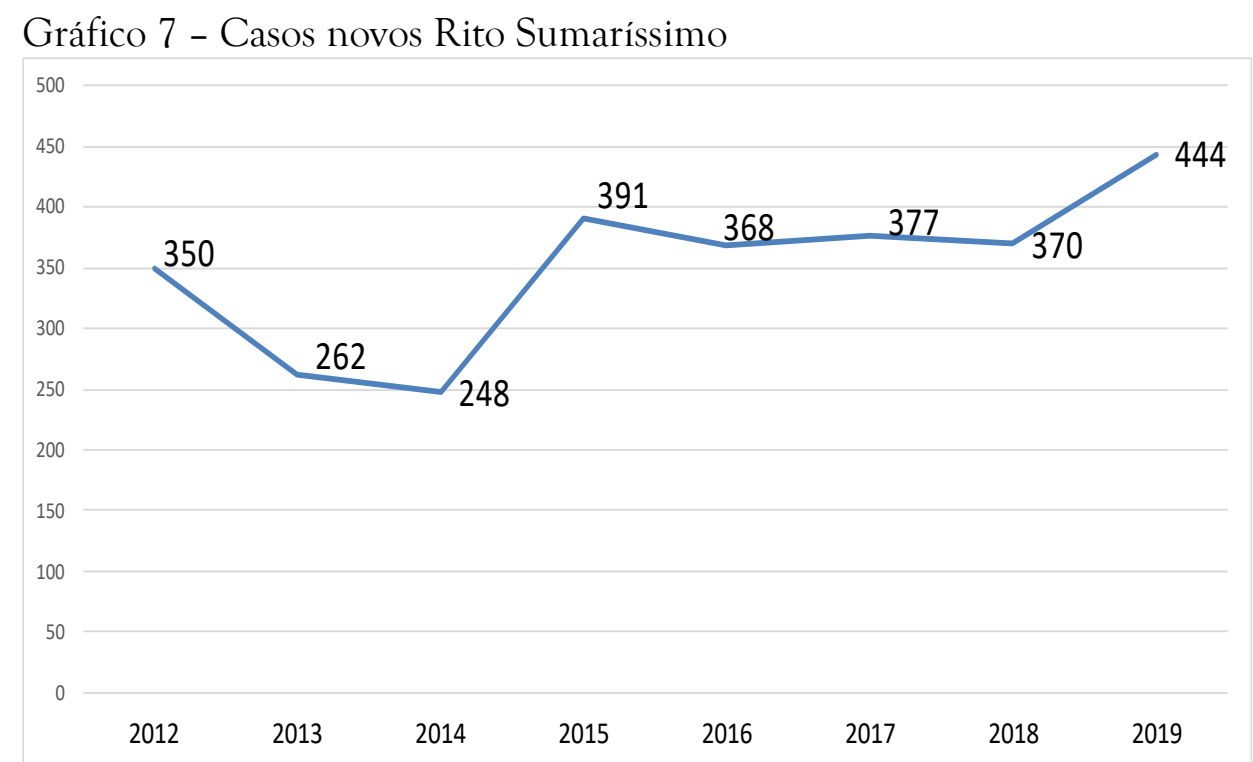

Fonte: dados secundários acessados via sistema do PJe - TRT4.

O art.852- $\mathrm{A}^{33}$ da CLT define o limite de 40 salário mínimos como um dos requisitos para que as ações integrem o rito sumaríssimo, mas a totalidade das ações que possuem como parte ente da administração pública ficam excluídas deste rito. Essa forma de organização legal faz com que parte importante das ações movidas contra a administração pública sejam unicamente propostas no rito ordinário. Assim, independentemente do valor da ação, o rito para os entes públicos será o ordinário.

A parte quantitativa da pesquisa não demonstra de forma robusta e convincente que a reforma tenha afetado os números de novos casos distribuídos no rito sumaríssimo, pois a elevação é suave.

O rito sumaríssimo é criado pela Lei no 9.957/2000 e normado na CLT no artigo 852-A-I que passa a definir um conjunto de peculiaridades.

33 "Art. 852-A. Os dissídios individuais cujo valor não exceda a quarenta vezes o salário mínimo vigente na data do ajuizamento da reclamação ficam submetidos ao procedimento sumaríssimo. Parágrafo único. Estão excluídas do procedimento sumaríssimo as demandas em que é parte a Administração Pública direta, autárquica e fundacional.” (BRASIL, 1943, online). 
As ações propostas sob o referido rito deveriam estar ajustadas às determinações do inciso I, nesta linha, a petição inicial apta ao ingresso na justiça do trabalho deverá estar com seus pedidos certos ou determinados e indicará o valor correspondente. Essa exigência foi levada para o rito ordinário a partir da reforma trabalhista ${ }^{34}$ como já descrito no item anterior.

Pelo gráfico abaixo, 2019 é o ano histórico em que o número de ações no rito sumaríssimo supera as ações no rito ordinário, podendo afirmar que tal variação é resultante das várias modificações legais impostas pela reforma ao ordenamento jurídico trabalhista e, mais suavemente, pela implantação do PJe, além de outros fatores não jurídicos ocorridos naquele ano.

Entre alguns profissionais da área jurídica trabalhista, existe certa comunhão de opiniões, por vezes críticas, de reconhecer a prática do denominado "demandismo trabalhista", e as novas exigências criadas pela reforma estariam obstando os abusos do exercício do direito de ação. Assim, a probabilidade de ganho era quase sempre certo e, muitas vezes, elevado antes da reforma. Há por outro lado uma clara percepção de que os empregadores sempre estão aquém das exigências legais definidas para os contratos de emprego pelo ordenamento trabalhista. Se, de um dos lados, há o demandismo, do outro, há uma leva expressiva de empregadores descumprindo, por vezes, de forma reiterada os preceitos trabalhistas, restando, quase sempre, alguma verba laboral ao final do contrato para ser buscada ou revisada na justiça.

Por outra via, a plataforma eletrônica de tramitação processual criou facilidades de acesso e atuação judicial por parte dos advogados que estavam ou que estão atuando na área trabalhista.

\footnotetext{
34“Art. 840 - A reclamação poderá ser escrita ou verbal. § 1. Sendo escrita, a reclamação deverá conter a designação do juízo, a qualificação das partes, a breve exposição dos fatos de que resulte o dissídio, o pedido, que deverá ser certo, determinado e com indicação de seu valor, a data e a assinatura do reclamante ou de seu representante. [...] $\S 3^{\circ}$. Os pedidos que não atendam ao disposto no $\S 1$ o deste artigo serão julgados extintos sem resolução do mérito." (BRASIL, 1943, online, grifo nosso).
} 
Efeitos da reforma trabalhista na justiça do trabalho: análise da dinâmica processual na segunda vara do trabalho de Santa Maria/RS

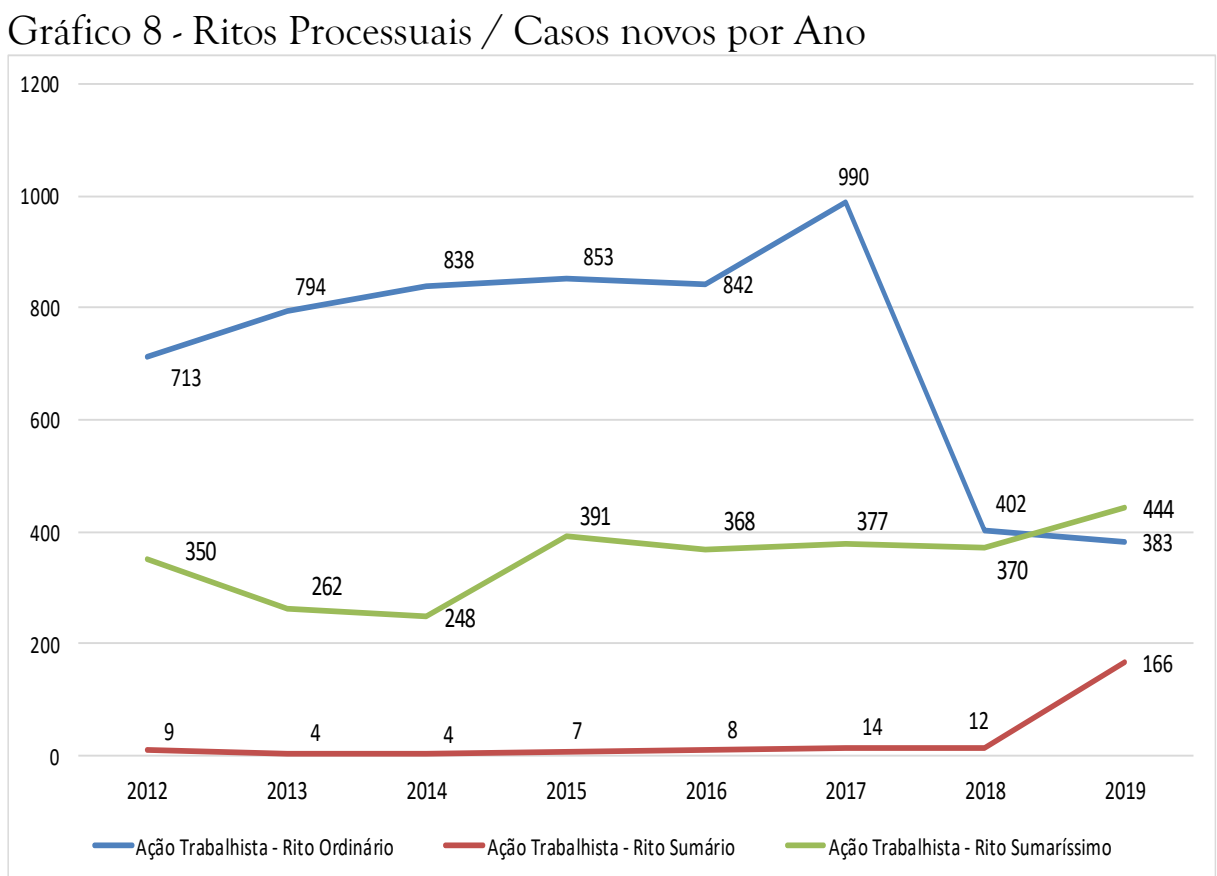

Fonte: dados secundários acessados via sistema do PJe - TRT4.

O tempo de tramitação processual no rito ordinário, ou melhor, a morosidade da justiça trabalhista na perspectiva de alguns profissionais, é outro fator que poderia estar deslocando as ações para o rito sumaríssimo, adicionando-se o fato de que o tempo total dos contratos de emprego pode estar sendo reduzido em vista das modificações legais (contrato intermitente) e das modificações econômicas dos últimos anos. $\mathrm{Na}$ mesma linha, infere-se que parte importante dos contratos de trabalho é resultado da terceirização, entre outras formas de contratação contemporâneas.

O tempo menor de contratação gera um valor menor à causa que, por ventura, irá nascer, gerando em consequência a mudança do rito processual.

\subsection{A REDUÇÃO DO NÚMERO DE HOMOlOGAÇÕES DE ACORDO EXTRAJUDICIAL DE 2018 PARA 2019}

Como reconhecer ou explicar os fatores que influenciaram o declínio das homologações de acordos extrajudiciais. 


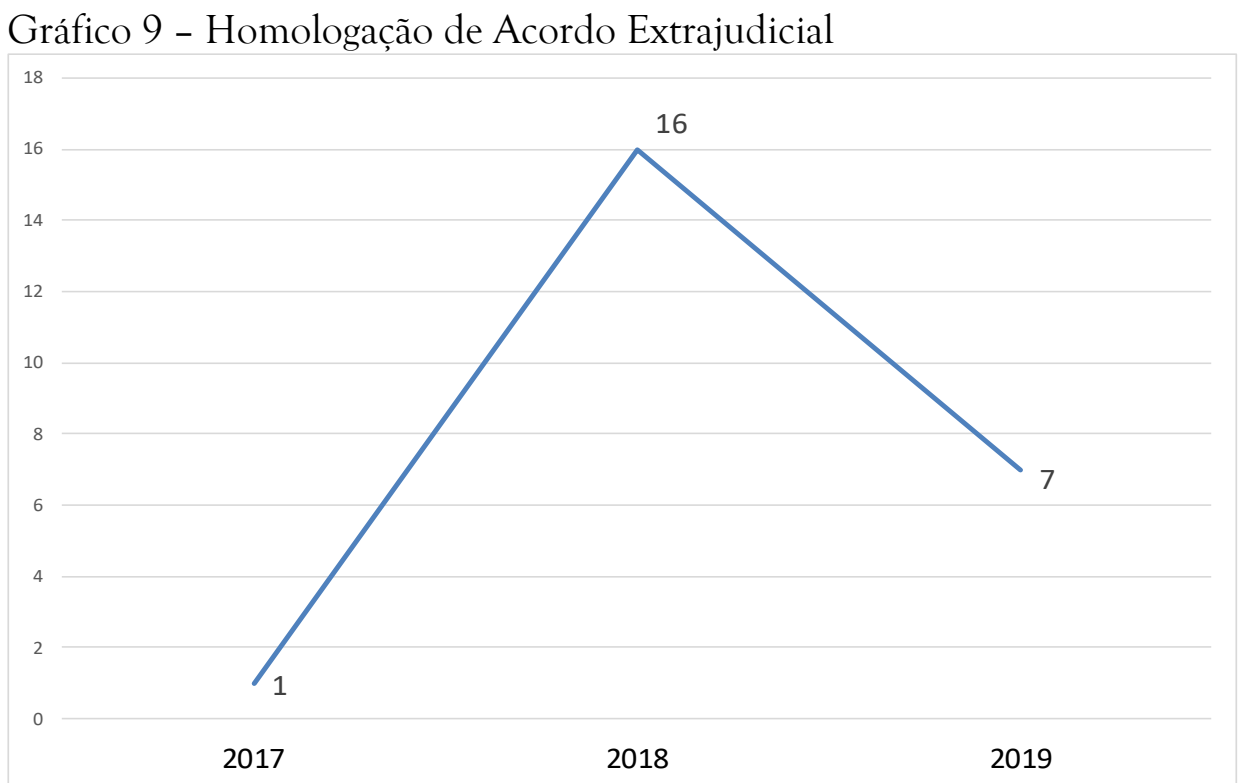

Fonte: dados secundários acessados via sistema do PJe - TRT4.

A Homologação de Acordo Extrajudicial é normada pela reforma e segue os preceitos do artigo 855- $\mathrm{B}^{35}$ e seguintes, bem como o artigo $652^{36}$ ambos da CLT.

Como foram encontrados 24 processos, os pesquisadores optaram por analisar todos eles - um a um - e tentar encontrar pistas judiciais aptas a dar início a uma possível explicação, ressalvando sempre a normalidade de tais quantitativos, em vista de acontecimentos da realidade econômica e laboral dos municípios que estão abrangidos na comarca da Justiça do Trabalho da Santa Maria/RS.

No ano de 2017:

01 acordo homologado, com a ressalva de retificação em parte das verbas a serem adimplidas.

No ano de 2018:

03 acordos não foram homologados;

01 acordo não foi homologado por desnecessidade;

04 acordos, de uma mesma empresa, foram homologados com retificação nas verbas rescisórias no INSS;

35 "Art. 855-B. O processo de homologação de acordo extrajudicial terá início por petição conjunta, sendo obrigatória a representação das partes por advogado. §1 ${ }^{\circ}$. As partes não poderão ser representadas por advogado comum. $\$ 2^{\circ}$. Faculta-se ao trabalhador ser assistido pelo advogado do sindicato de sua categoria. Art. 855-C. O disposto neste Capítulo não prejudica o prazo estabelecido no $\S 6^{\circ}$ do art. 477 desta Consolidação e não afasta a aplicação da multa prevista no $\S 8^{\circ}$ art. 477 desta Consolidação. Art. 855-D. No prazo de quinze dias a contar da distribuição da petição, o juiz analisará o acordo, designará audiência se entender necessário e proferirá sentença. Art. 855-E. A petição de homologação de acordo extrajudicial suspende o prazo prescricional da ação quanto aos direitos nela especificados. Parágrafo único. O prazo prescricional voltará a fluir no dia útil seguinte ao do trânsito em julgado da decisão que negar a homologação do acordo.” (BRASIL, 1943, online).

36 "Art. 652. Compete às Varas do Trabalho: a) conciliar e julgar: [...] f) decidir quanto à homologação de acordo extrajudicial em matéria de competência da Justiça do Trabalho." (BRASIL, 1943, online). 
Efeitos da reforma trabalhista na justiça do trabalho: análise da dinâmica processual na segunda vara do trabalho de Santa Maria/RS

03 acordos homologados, com retificações na parcela e no recolhimento ao INSS e/ou IR;

01 acordo homologado com ressalva as contribuições do INSS;

$\underline{04}$ acordos homologados sem retificação ou ajustes.

No ano de 2019:

04 acordos homologados com ressalvas e anotação da CPTS;

03 acordos homologados sem retificações ou ajustes.

Do total das 24 ações propostas buscando homologação de acordo extrajudicial, apenas 7 foram homologadas sem qualquer ressalva judicial.

Em sua maioria, os juízes do trabalho buscam aplicar a lei aos casos que são propostos na vara do trabalho em estudo, nesse sentido, foi perceptível que o crivo judicial e as irregularidades (ou fraudes) praticadas ao tempo do contrato foram retificadas, a exemplo da assinatura da CTPS, recolhimentos previdenciários, imposto de renda, registro de tempo de serviço na CTPS entre outros.

Tais intervenções judiciais podem ter desestimulado as partes em buscar o procedimento de homologação judicial, sendo uma das hipóteses aptas a explicar o declínio do número de casos novos de 16 no ano de 2018 para 7 no ano de 2019.

Enfim, como as partes acordantes foram surpreendidas com atuação corretiva e retificadora dos magistrados que atuam na vara do trabalho, tal fato teria o condão de que os novos ajustes não sejam entendidos como meras liberalidades das partes que serão acatadas em juízo, diferente do que poderia ocorrer na justiça comum em acordos de cunho civil.

\section{CONSIDERAÇÕES FINAIS}

A mudanças operadas pela Reforma Trabalhista impactaram em medidas distintas a dinâmica processual na Justiça do Trabalho.

Os dados quantitativos apresentados pelo sistema do TRT4 foram fundamentais para destacar e nortear o estudo, em vista de que a realidade judicial pode incorporar o "número" como técnica e abordagem de compreensão dos fenômenos judiciais, ou melhor, a sistematização tecnológica dos processos judiciais irá gerar um campo ilimitado de informações quantitativas que ficarão à disposição dos pesquisadores do direito.

Com lapsos temporais de 04 anos de vigência do Código de Processo Civil, que afetou alguns procedimentos judiciais laborais, os 03 anos da Reforma Trabalhista, somados aos 05 anos de implantação do PJe, começam a ganhar destaque algumas relevantes estatísticas que resultam em acontecimentos fáticos e judiciais vivenciados pelos profissionais que atuam na Justiça do Trabalho. Por outro lado, mesmo sendo 
exíguos tais lapsos temporais, a realidade judicial apresenta algumas pistas aptas a serem analisadas e compartilhadas.

Não há propriamente uma pretensão doutrinária neste artigo, os autores se propuseram a analisar as mudanças legislativas aptas a explicar as variações quantitativas apresentadas pelos dados gerados pelo sistema do Tribunal Regional do Trabalho da $4^{\circ}$ Região, a contar do ano de 2012 até outubro de 2019.

Assim sendo, os impactos mais relevantes foram a elevação do número de ações de cumprimento; a redução do número de ações ajuizadas no rito ordinário; a elevação do número de ações ajuizadas no rito sumário; a suave elevação do número de ações ajuizadas no rito sumaríssimo e a redução do número de homologações de acordos extrajudiciais. Desta forma, a reforma trabalhista gerou certa mudança na dinâmica das ações judiciais a partir de sua publicação e vigência.

Os itens analisados foram selecionados a partir das variações quantitativas, e estas foram conectadas às mudanças legislativas que as precederam. Desse modo, a reforma trabalhista foi capaz de alterar tanto a dinâmica processual como a atuação laboral dos profissionais que atuam na área trabalhista (advogados e contadores).

A pesquisa realizada na Segunda Vara do Trabalho de Santa Maria/RS pode ser considerada uma iniciativa ainda mais interessante se conseguirmos replicar nas demais varas do trabalho do Estado ou no país. Destas, nasceria a possibilidade de aproximar as várias realidades municipais e regionais que terão, em vista de suas peculiaridades, dados díspares, similares e complementares.

\section{REFERÊNCIAS}

ANAMATRA. Associação Nacional dos Magistrados da Justiça do Trabalho. Disponível em: https://www.anamatra.org.br/attachments/article/27175/livreto_RT_ Jornada_19_Conamat_site.pdf. Acesso em: 10 jan. 2020.

BOURDIEU, Pierre; PASSERON, Jean-Claude; CHAMBOREDON, Jean-Claude. Ofício de sociólogo: metodologia da pesquisa na sociologia. 5.ed. Petrópolis: Vozes, 2004 .

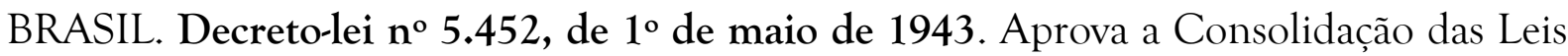
do Trabalho. Brasília, DF: Presidência da República, 1943. Disponível em: http://www.planalto.gov.br/ccivil_03/decreto-lei/del5452.htm. Acesso em: 16 abr. 2020 .

BRASIL. Constituição da República Federativa do Brasil de 1988. Brasília, DF: Presidência da República, 1988. Disponível em: http://www.planalto.gov.br/ccivil_03/constituicao/constituicao.htm. Acesso em: 16 abr. 2020. 
Efeitos da reforma trabalhista na justiça do trabalho: análise da dinâmica processual na segunda vara do trabalho de Santa Maria/RS

BRASIL. Código de processo civil. Brasília, DF: Presidência da República, 2015. Disponível em: http://www.planalto.gov.br/ccivil_03/_ato20152018/2015/lei/113105.htm. Acesso em: 1 jan. 2020.

BRASIL. Lei $\mathrm{n}^{\mathrm{o}}$ 5.584, de 26 de junho de 1970. Dispõe sobre normas de Direito Processual do Trabalho, altera dispositivos da Consolidação das Leis do $T$ rabalho, disciplina a concessão e prestação de assistência judiciária na Justiça do Trabalho, e dá outras providências. Brasília, DF: Presidência da República, 1970. Disponível em: http://www.planalto.gov.br/ccivil_03/leis/15584.htm. Acesso em: 17 abr. 2020.

BRASIL. Projeto de Lei 6787/2016 (Reforma Trabalhista). Disponível em: https://www2.camara.leg.br/atividade-legislativa/discursos-e-notas-taquigraficas/discur sos-em-destaque/projeto-de-lei-no-6787-2016-reforma-trabalhista/projeto-de-lei-no-67872016-reforma-trabalhista-1. Acesso em: 10 out. 2019.

DELGADO, Maurício Godinho. Curso de Direito do Trabalho: obra revista e atualizada conforme a lei da reforma trabalhista e inovações normativas e jurisprudenciais posteriores. 18. ed. São Paulo: LTr, 2019.

QUIVY, Raymond; CAMPENHOUDT, Luc Van. Manual de investigação em ciências sociais. 4. ed. Lisboa: Gradativa, 2005.

RAMOS, Luís Leandro; GALIA, Rodrigo Wasem. Assédio moral e cyberbullying no trabalho. Belo Horizonte: Editora D Plácido, 2019.

SUPIOT, Alain. Critique du droit du travail. Paris: Presses Universitaires de France, 1994.

WEBER, Max. O direito na economia e na sociedade. Tradução Marsely de Marco Martins Dantas. São Paulo: Ícone, 2011. (Coleção Fundamentos do Direito).

\section{NOTA}

Declaramos que o artigo intitulado "EFEITOS DA REFORMA TRABALHISTA NA JUSTIÇA DO TRABALHO: ANÁLISE DA DINÂMICA PROCESSUAL NA SEGUNDA VARA DO TRABALHO DE SANTA MARIA/RS”, submetido à Revista Opinião Jurídica, representa fruto direto das pesquisas desenvolvidas pelos autores, sobretudo no âmbito das atividades do Grupo de Pesquisas "RETRADE - As Relações de Trabalho no Século XXI e os Novos Desafios na Sociedade em Rede" - cadastrado no CNPQ, tendo ambos (Líderes do Grupo de Pesquisa em questão) realizado, concomitantemente, as tarefas de seu planejamento, execução e revisão da seguinte forma: 1) Paulo José Libardoni: desenvolveu de forma mais específica a análise quantitativa dos dados da 2a Vara do Trabalho de Santa Maria - RS; e 2) Rodrigo Wasem Galia: aliou à pesquisa quantitativa à pesquisa doutrinária e jurisprudencial, 
tendo elaborado o resumo, a introdução, as considerações finais do presente trabalho, focando na Reforma Trabalhista operada pela Lei $\mathrm{n}^{\circ} 13.467 / 2017$, tendo ambos os autores feito a releitura atenta do artigo e procedido às arrumações apontadas pelos revisores AD HOC da Revista.

Como citar este documento:

LIBARDONI, Paulo José; GALIA, Rodrigo Wasem. Efeitos da reforma trabalhista na justiça do trabalho: análise da dinâmica processual na segunda vara do trabalho de Santa Maria/RS. Revista Opinião Jurídica, Fortaleza, v. 19, n. 30, p.118-148, jan./abr. 2021. 